\title{
Mouse Models of Congenital Kidney Anomalies
}

\author{
Kuure, Satu
}

SPRINGER-VERLAG SINGAPORE PTE LTD

2020

Kuure , S \& Sariola , H 2020 , Mouse Models of Congenital Kidney Anomalies . in A Liu (ed.) , ANIMAL MODELS OF HUMAN BIRTH DEFECTS . Advances in Experimental Medicine and Biology , vol. 1236 , SPRINGER-VERLAG SINGAPORE PTE LTD , pp. 109-136 . https://doi.org/10.1007/978-98

http://hdl.handle.net/10138/329144

https://doi.org/10.1007/978-981-15-2389-2_5

acceptedVersion

Downloaded from Helda, University of Helsinki institutional repository.

This is an electronic reprint of the original article.

This reprint may differ from the original in pagination and typographic detail.

Please cite the original version. 


\section{Chapter 5}

\section{Mouse models of congenital kidney anomalies}

Satu Kuure ${ }^{1,2,3, *}$ \& Hannu Sariola ${ }^{3,4}$

${ }^{1}$ GM-unit, Helsinki Institute of Life Science, University of Helsinki, Finland

${ }^{2}$ Stem Cells and Metabolism Research Program, Faculty of Medicine, University of Helsinki, Finland

${ }^{3}$ Medicum, Faculty of Medicine, University of Helsinki, Finland

${ }^{4}$ Paediatric Pathology, HUSLAB, Helsinki University Central Hospital, Finland

*Correspondence: satu.kuure@helsinki.fi 
Overview 4

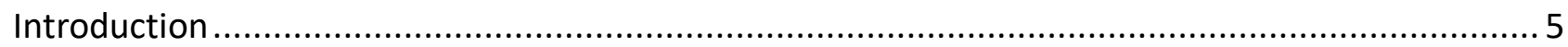

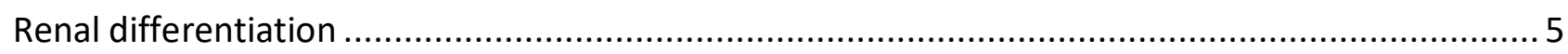

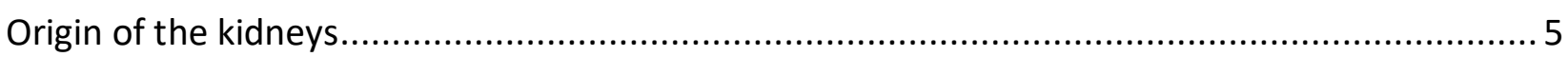

Development of the permanent kidney (metanephros) .................................................. 6

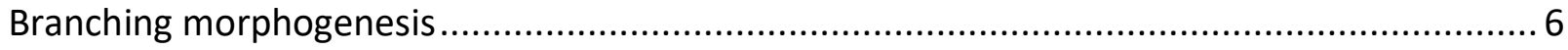

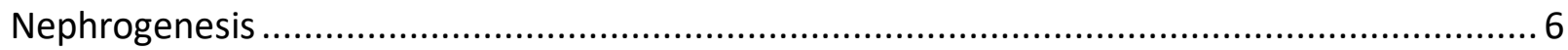

Mouse as a mannequin of renal disease in man - inborn errors and effective dissimilarities ......... 7

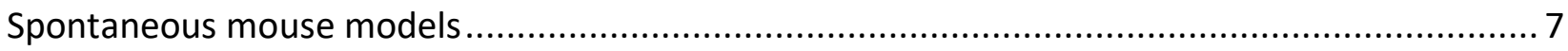

Genetically modified mouse models .......................................................................... 8

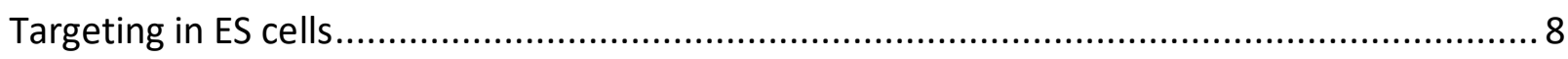

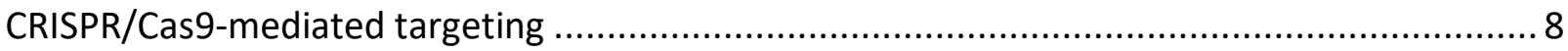

Common renal malformations in human fetal autopsies and their analogous mouse models ......... 9

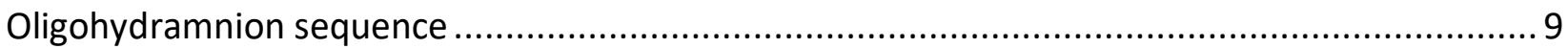

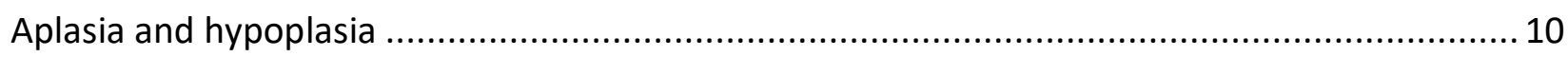

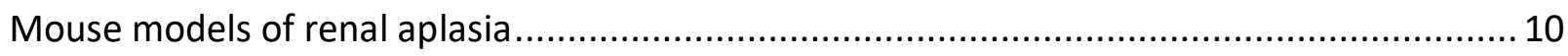

Mutations identified in human renal aplasia ................................................................ 11

Mutations in human renal hypoplasia and hypodysplasia ................................................. 11

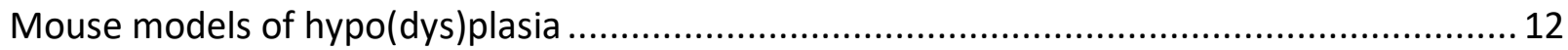

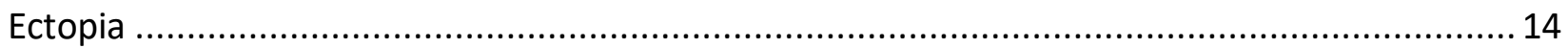

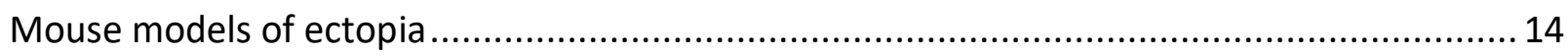

Mutations identified in human renal ectopia .................................................................. 14

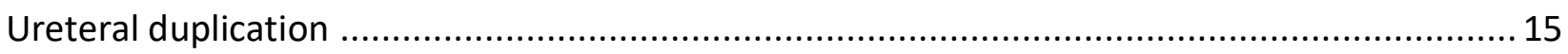

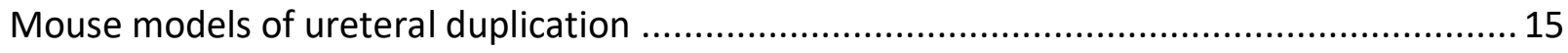

Mutations identified in human ureteral duplications .................................................... 15

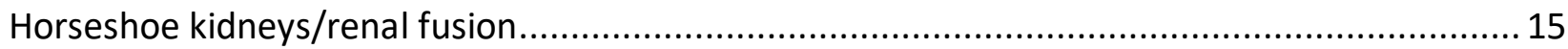

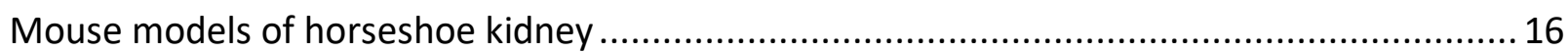

Mutations identified in human horseshoe kidneys ....................................................... 16

Renal multi-cystic dysplasia and polycystic kidney disease ............................................ 16

Mutations identified in humans with renal cysts ............................................................ 17

Mouse models of cystic kidney and polycystic kidney disease .......................................... 17

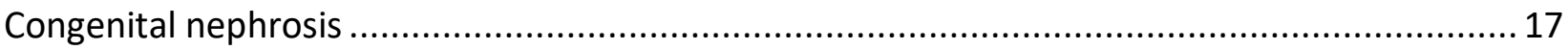

Mutations causing congenital nephrotic syndrome in humans ..................................... 18 
Mouse models of congenital nephrotic syndrome

Nephroblastomatosis (nephrogenic rests) and Wilms' tumor ............................................. 18

Mutations and syndromes associated with Wilms' tumor in humans ................................... 18

Mouse models of nephroblastomatosis and Wilms' tumor ............................................. 19

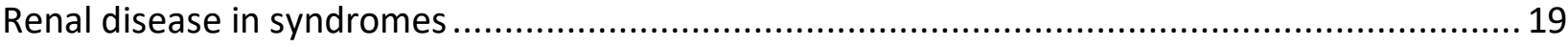

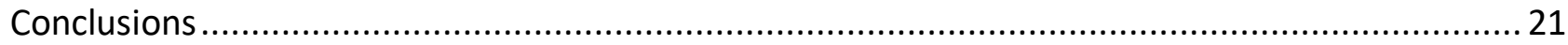

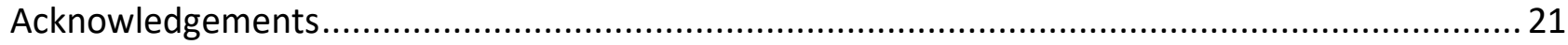

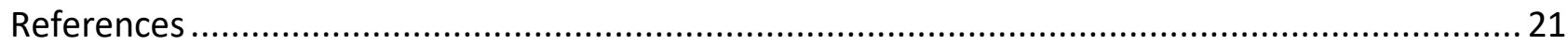




\section{Overview}

Congenital anomalies of the kidney and urinary tract (CAKUT) are common birth defects, which cause the majority of chronic kidney diseases in children. CAKUT covers a wide range of malformations that derive from deficiencies in embryonic kidney and lower urinary tract development, including renal aplasia, hypodysplasia, hypoplasia, ectopia, and different forms of ureter abnormalities. The majority of the genetic causes of CAKUT remain unknown. Research on mutant mice has identified multiple genes that critically regulate renal differentiation. The data generated from this research have served as an excellent resource to identify the genetic bases of human kidney defects and have led to significantly improved diagnostics. Furthermore, genetic data from human CAKUT studies have also revealed novel genes regulating kidney differentiation. 


\section{Introduction}

Congenital anomalies of the kidney and lower urinary tract (CAKUT) are caused by inborn defects in the differentiation of the organs, including the kidneys as well as the urine excretion organs. In order to understand the potential genetic, molecular, and cellular bases of these malformations, it is essential to comprehend how these organs normally develop.

A large part of our understanding of mammalian kidney formation comes from the early inductive studies carried out by Clifford Grobstein and Lauri Saxén. It rapidly became evident that the development of the kidney is controlled through reciprocal inductive tissue interactions (1-3). Since then, we have learned that the interacting tissues in the kidney rudiment are the ureteric bud (UB) epithelium, derived from the Wolffian duct (WD, also known as nephric duct), the metanephric mesenchyme ( $\mathrm{MM}$, also called renal mesenchyme) in close proximity to the $U B$, and the stromal cells surrounding the MM. The inductive interplay between these tissues results in developmental changes in the nascent tissue, which reciprocally affects the signal-sending tissue. These interactions are largely mediated by direct cell-cell contacts, secreted paracrine morphogens, and other as-yet-unknown mechanisms.

\section{Renal differentiation}

\section{Origin of the kidneys}

The kidneys originate from the intermediate mesoderm (IM). Recent advances in understanding the early specification of kidney precursors revealed that $\mathrm{IM}$ is temporally regionalized, and the interacting tissues of the developing kidney are derived from its distinct subpopulations $(4,5)$. The most anterior IM is the first to form and gives rise to the WD and its derivatives, whereas the posterior IM differentiates into MM and stroma. Initially, IM undergoes mesenchyme-to-epithelium transition (MET) to generate the WD, which begins to grow posteriorly simultaneously to MM specification in the leading front of the WD.

Mammalian kidney differentiation involves the formation of three sets of sequentially formed distinct kidneys $(6,7)$. During the posterior growth of the WD, the first kidneys to form are the pronephroi, which are transient organs with no known function in mammals (Figure 5.1A). The next kidneys to develop are the mesonephroi. Each mesonephos in humans contains a total of 34 mesonephric tubules all connected to the WD, and is functional during the early phases of fetal life (Figure 5.1B). They secrete urine and form aorta-gonad-mesonephros region, which hosts hematopoietic stem cells (8). In mouse, where the mesonephroi are non-functional organs, there are two distinct sets of mesonephric tubules of which the 4-6 cranial pairs are connected to the WD while the majority of the caudal tubules remain without direct connection to the WD (9). The last kidneys are the metanephroi, the permanent kidneys, which start functioning after mid-gestation and play an important role in fetal health by excreting primary urine to become the amniotic fluid (Figure 5.1C). In fact, one phenotypic change in newborns with defective kidney function is the socalled Potter's sequence (oligohydramnion sequence). Here, a reduced amount of amniotic fluid caused by minimal urine production gives rise to the characteristic fetal features including flattened nose and abnormalities around the eyes and ears, club-feet, and small lungs (pulmonary hypoplasia) resulting in respiratory insufficiency. 
The development of the permanent kidney, the metanephros, begins at approximately embryonic day 30-32 (E30-32) in humans and at E10.5 in mice when the caudal end of the WD has made contact with the cloaca, the future bladder, and bulges towards the medial-dorsally located MM (10). The initial bulge then rapidly elongates and invades the MM to form the UB. The bud at this stage is already divided into the tip and trunk regions, which bear divergent molecular signatures and show different cellular behaviors (Figure 5.2). The UB tip, which is intimately surrounded by $\mathrm{MM}$, is highly proliferative, includes actively moving individual cells, and is surrounded by discontinuous and scarce extracellular matrix. The UB trunk, on the other hand, shows a significantly lower rate of cell division as its elongation is dominated by convergent extensions. It also begins to build up distinct, continuous extracellular matrix characteristic of the collecting ducts and ureter.

\section{Branching morphogenesis}

The UB tip is surrounded by the MM, which is more tightly packed near the UB epithelium than the more distally located stromal mesenchyme in the outer most layer of the developing kidney (Figure 5.2). After its formation, the UB starts dichotomous branching morphogenesis, instructed by signals derived from the MM (11). First, an existing tip balloons to form an ampulla, which then bifurcates into two new tips that thereafter elongate to generate new trunks $(12,13)$. Genetic labeling experiments together with live-imaging of cultured kidneys at the single-cell level have revealed that some tip cells are maintained within the tips while others are left behind in trunk regions (14-17). This has led to a relatively well-proven model where the UB tips host progenitor cells for the entire collecting duct, composed of intercalated and principal cells. Currently, the molecular regulation and cell-specific gene signatures to distinguish progenitors from the cells destined for differentiation are missing, but improvements in single-cell transcriptomic techniques together with the possibility to spatially map multiple gene expressions simultaneously are expected to shed light on this currently stochastic-seeming process $(18,19)$. Finally, it has been estimated that the mouse UB undergoes some 11-12 rounds of repeated branching events to finally generate the shape of the organ with collecting ductal system of an appropriate complexity (20). In addition to branching, the collecting ducts undergo complex reorganization at mid-gestation to form pelvis and distinct medulla-cortex compartmentalization (21).

\section{Nephrogenesis}

Nephron differentiation begins simultaneously to the start of branching morphogenesis (Figure 5.2). Nephrons are derived from the subpopulation of metanephric mesenchyme called cap mesenchyme, which is defined by its tight and oriented arrangement of mesenchymal cells around UB tips $(13,22-24)$. These nephron progenitors both self-renew to maintain the cap mesenchyme until cessation of nephrogenesis and differentiate through MET into specialized epithelial cells of all nephron segments (25-27). Nephron progenitors (NPs) are maintained in the cap mesenchyme surrounding each newly formed UB tip, while their differentiation takes place in the nascent mesenchyme of same tip. The molecular regulation of NP specification and maintenance involves both intrinsic (cell autonomous) and UB-derived paracrine pathways, which merge to balance between self-renewal versus differentiation. Nephrogenesis begins by the compaction of NP cells into the armpits of the T-shaped UB, after which this so-called pretubular aggregate epithelializes 
via the characteristic morphological stages of renal vesicle, comma-shaped and S-shaped bodies to form a secretory nephron (Figure 5.2). Thus, the final nephron number in each individual closely reflects the extent of UB branching $(3,20)$. Each segment of nephron, namely the podocytes of glomeruli, Bowman's capsule, the proximal tubules, the loop of Henle, the distal tubules, and the connecting piece joining the nephron to the collecting duct system derives from the same NP pool. The causes of NP exhaustion and the end of nephrogenesis at late gestation in humans (week 36) or at early postnatal days in mice $(P 3)(28,29)$ are not known.

\section{Mouse as a mannequin of renal disease in man - inborn errors and effective dissimilarities}

Different animals have been used to aid the understanding of the mechanisms guiding differentiation since the early days of developmental biology studies. Modern research largely relies on rodents as mammalian models, and due to the development of genetic manipulation techniques (see below) specific for house mouse, Mus Musculus, it has become the predominant animal model in kidney development.

The mouse as an experimental animal comes in various different flavors. The fact that over 450 inbred mouse strains exist translates into a wealth of different genotypes and phenotypes for those utilizing the mouse as a model of diseases in human (30). Moreover, laboratory mice are also maintained as outbred strains, expanding the complexity even further. In reality, researchers worldwide focus on using many of the same inbred strains, which are employed in experiments with genetically modified mouse models (see below). For the purpose of renal diseases, it is important to remember that both gender and genetic variations in the inbred strains very much influence e.g. predisposition to kidney damage. In other words, some strains, like C57BL/6, are rather resistant to kidney damage and develop proteinuria, glomerulosclerosis, and/or hypertension only when highly damaged (31). This likely derives from the different accumulation of genetic aberrations between the strains as e.g. C57BL/6 only has one functional gene for renin, resulting in a decreased reninangiotensin-aldosterone system as compared to e.g. 129/Sv substrains (32). Moreover, female mice in general better tolerate ischemic renal damage and chemically-induced diabetic nephropathy than male mice.

\section{Spontaneous mouse models}

Mice with inborn errors in kidney differentiation resulting in renal aplasia (33), lupus nephritis, polycystic kidney disease, interstitial disease, hypertension, and diabetes-induced nephropathy have greatly facilitated our understanding of the pathogenesis and mechanisms of renal diseases (34). Classical mutations such as Danforth's short tail (Sd) and limb deformity (Id) cause renal aplasia due to failure to induce UB formation and growth (35). The first model of autosomal polycystic kidney disease, the $c p k / c p k$ mouse, represents an aggressive, early-onset renal disease, especially in the DBA/2J strain(36). Similarly, $b p k / b p k$ and $p c y / p c y$ mice show inherited proximal tubule cystogenesis, which eventually spreads into all nephron segments. Though great models for diabetic nephropathy are still to come, NOD mice have been widely used for type I 
diabetes-associated nephropathy, while the corresponding model for type II diabetic nephropathy are the $d b / d b$ mice (37).

\section{Genetically modified mouse models}

The mouse became the most popular species in genetic engineering due to the early availability of its genome sequence, the possibility to derive and successfully culture its embryonic stem (ES) cells, and its relative similarity to human physiology. Previously, the possibilities to manipulate mammalian genomes were limited to chemically-induced random mutagenesis (forward genetic approach such as ENU mutagenesis), radiation, and non-targeted integration of foreign DNA (transgenesis). Though rather imperfect, these strategies have provided not only the basis for the more modern techniques currently in use but also advanced our understanding of many complex biological processes. Due to the current predominance of targeted genome editing approaches (reverse genetics), these techniques, which are utilized to produce point mutations, large deletions, and conventional and conditional knockout mouse lines, are shortly described below.

\section{Targeting in ES cells}

Genetic engineering of mouse ES cells in combination with the techniques allowing aggregation of mutated and wild-type ES cells to generate chimeric embryos has been the basis for the generation of gene knockouts and conditional alleles for the last two decades (38). The key requirement is that the locus of the gene-of-interest is known and cloned, as this is utilized to build a targeting vector, which includes not only the disrupted gene-of-interest, but also 5' and 3' sequences around it. The surrounding sequences, known as homology arms, anneal to the corresponding region of the genome in ES cells and allow replacement of the endogenous gene through homologous recombination.

Classically, a neomycin resistance gene in the targeting vector is used to inactivate the geneof-interest. Alternatively, the generation of point mutations and conditional alleles requires insertion of a desired genetic alteration, e.g. the nucleotide change or loxP sequences, to the targeting vector (39). As homologous recombination is a rare event in any cell, neomycin resistance and thymidine kinase genes in the targeting vector are used to identify those ES cells where the endogenous gene is replaced with the targeted gene (40). After confirming the successful targeting by sequencing, the ES cells are introduced into wild-type morulae or blastocysts by aggregation or injections, respectively. Host embryos typically originate from a different mouse strain than the targeted ES cells, allowing identification of the genetically engineered pups by their chimeric coat color. The final requirement for the establishment of a new genetically engineered mouse line is that the chimeric founder transmits the desired gene editing to its offspring. In general, the traditional targeting strategy is a lengthy and expensive procedure where the generation of genemodified mouse line typically takes 18-24 months.

\section{CRISPR/Cas9-mediated targeting}

The revolution of genetic engineering began with the development of programmable, highly specific DNA nucleases of which the first ones, zinc finger nucleases (ZFN) and transcription 
activator-like effector nucleases (TALEN), were based on modifiable DNA domains that guide the Fok1 nuclease to a specific genomic location (41). The next generation genome editing now utilizes short RNA guides to specifically locate CAS9 endonuclease (originating from the bacterial immune system) to the desired site in the genome. All these editing systems are ideologically similar as they are based on nuclease function, which cuts DNA to generate double strand breaks that activate the endogenous repair systems in any given cell type (42). The predominant repair system is nonhomologous end joining, which is error prone and results in inactivation of the gene-of-interest by introducing small nucleotide insertions and deletions that disrupt the normal reading frame. In animal model generation, this is achieved through injection of RNA guides together with CAS9 (mRNA or protein) into the fertilized oocyte. Injected zygotes then develop into conventional knockout founders, each with a slightly different disruption in the gene-of-interest. The CRISPR/CAS9-based gene inactivation is applicable not only in mice but also in many other species. It has proven to be an efficient and inexpensive method that is an extremely attractive and useful tool for genome editing in development of different disease models.

Opposed to the ease of generating knockouts with CRISPR/CAS9, targeted insertion of additional genetic material into the host genome is more difficult. Targeted insertion is necessary when the goal is to faithfully mimic human diseases, like those caused by congenital kidney defects as the result of point mutations or short deletions. Similar to ES cell targeting, this requires the engagement of homologous recombination, which is inefficient due to its uncommon occurrence. Additional challenges in the generation of knockin models come from the fact that CRIRSP/CAS9 is particularly efficient in genome editing through non-homologous end joining, which is activated simultaneously to homologous recombination. This unfortunately results in additional, undesired editing near the point mutation containing template DNA. Careful design, use of control animals, and genotyping of the founder animals as well as F1 offspring by sequencing are needed to ascertain that possible phenotypic alterations derive from the anticipated edit and not from the extra editing in an undesired locus (43).

\section{Common renal malformations in human fetal autopsies and their analogous mouse models}

\section{Oligohydramnion sequence}

The founder of pediatric pathology in the USA, Edith Potter (1901-1993), first described the oligohydramnion sequence. It is caused by the lack of the amniotic fluid, a condition called oligohydramnion. Amniotic fluid is predominantly urine, and oligohydramnion is thus caused by the lack of the kidneys (bilateral renal aplasia), urethral valve (thin membrane blocking the urethra) preventing urination, or premature rupture of the fetal membranes (PROM). Placental insufficiency, for instance in pre-eclampsia, can also cause oligohydramnion. Amniotic fluid contains a number of growth factors, and as the fetus inhales amniotic fluid, the factors promote the growth and maturation of the lungs. Oligohydramnion sequence is characterized by typical external features and small lungs (pulmonary hypoplasia), which can cause postnatal respiratory insufficiency and high neonatal mortality rates. 
Lack of one or both kidneys is referred to as uni- or bilateral renal aplasia. If the kidneys are smaller than expected for the developmental or newborn stage, they are hypoplastic. The genetic causes of renal aplasia have been only partially resolved, but a common environmental cause for renal hypoplasia is the lack of vitamin $A(44,45)$. The biologically inactive vitamin $A$ is locally activated to become retinoic acid by the retinaldehyde dehydrogenase 2 enzyme (RALDH2 also known ALDH2) synthesized by the renal interstitial or stromal cells (46).

\section{Mouse models of renal aplasia}

Analysis of spontaneous and knockout mouse models has revealed several causes of renal aplasia and thus has helped understanding of the mechanisms leading to congenital absence of kidneys in humans (33). Among the first aplasia models are Danforth's short tail ( $s d$ ) spontaneous mouse mutant, which is caused by disruption of pancreas specific transcription factor, 1a (Ptf1a) with transposon insertion (47), and formin mutation resulting in limb deformity (Id) model (48). Genetic inactivation of a single mouse gene, such as the transcription factor Pax2 (49), Osr1 (50, 51), Gata1 (52), Lhx1 (53, 54), Wt1 (55), Hox11 $(56,57)$, Eya1 (58), Six1 (59), or Sall1 (60) arrests renal differentiation due to defects in early specification of intermediate mesoderm (Osr1), formation of WD (Gata3 and Lhx1), or induction of the kidney itself. The lack of kidney induction is typically caused by either the failure to induce primary UB formation (Eya1, Hox11, Pax2, Six1, Sall1) leading to subsequent apoptosis of the MM, or the inability of the MM to survive (Wt1).

In addition to transcription factors, deletion of the specific components in key growth factor signaling pathways causes renal aplasia (25). Characterization of mouse mutants lacking genes for glial cell line derived neurotrophic factor $(\operatorname{Gdnf}(61-63))$ or its receptor complex (Ret $(64,65)$ and coreceptor Gfra1 $(66,67))$ revealed renal aplasia due to impaired UB formation (68). Also, simultaneous deletion of Etv4 and -5, the first identified GDNF/RET-dependent transcription factors, causes renal aplasia $(16,69)$. GDNF belongs to transforming growth factor beta (TGF $\beta$ ) superfamily, and unlike the TGF $\beta$ genes themselves, another TGF $\beta$ superfamily member, growth/differentiation factor 11 (GDF11) is necessary for normal UB formation (70-73). Deletion of Gdf11 results in a spectrum of renal abnormalities with bilateral aplasia being the most frequent (70). Interestingly, several genetic studies in mice imply that the level of bone morphogenetic protein (BMP) signaling, also belonging to TGF $\beta$ superfamily, is essential for normal UB outgrowth and early organogenesis of the kidney. Not only is too little or missing signaling harmful, but enhanced levels also result in abnormalities, as shown by renal aplasia in mice with knockout of BMP antagonist Gremlin1 (74-76).

The fibroblast growth factor (FGF) cascade works parallel to GDNF/RET signaling as shown by the conditional deletion of FGF receptors 1 and 2 with Pax3Cre (77). The UB forms in the absence of the FGF receptors, but its subsequent elongation and branching are arrested leading to renal aplasia. Many FGF ligands are expressed in the developing kidney, suggesting redundancy in their signaling. Accordingly, inactivation of one FGF receptor, but not a single FGF ligand, causes renal aplasia, supporting the essential functional importance of FGF signaling for kidney differentiation (78). Furthermore, simultaneous disruption of $F g f 9$ and -20 results in renal aplasia, likely due to deficiency in UB formation; although, this is not experimentally confirmed (79).

Inactivation of wingless-type MMTV integration site family (WNT) signaling by deleting $W n t 9 b$ results in renal aplasia in mouse (80). Unlike many other aplasia models with early UB arrest, 
the loss of Wnt9b primarily affects the MM, which fails to maintain nephron progenitors and induce them for differentiation $(81,82)$. Canonical WNT signaling is mediated by inactivation of glycogen synthase 3 (GSK3) and causes stabilization of cytoplasmic $\beta$-catenin, which leads to activation of TCF/LEF1 transcription factors. Numerous experiments have demonstrated that canonical WNT signaling is essential for UB branching, collecting duct morphogenesis, and nephron induction as well as differentiation (83) (for details, see the section on Mouse models of hypoplasia). Of note, simultaneous deletion of Gsk3a and - $b$ specifically in the collecting duct results in renal aplasia (ASN Kidney Week 2011, https://www.asn-online.org/abstracts/), unlike similar deletion of $b$-catenin, which usually causes hypodysplasia (84).

Genes encoding essential structural proteins, such as those related to cell adhesion and extracellular matrix, are also vital for early kidney specification and induction. A good example is integrin-linked kinase (ILK), which binds the cytoplasmic domains of b-integrin to regulate actin dynamics and when deleted, results in renal aplasia (85). However, a single gene deletion of a structural protein often appears without a phenotype, probably because of compensation or redundancy by another family member, or results in an incompletely penetrant renal aplasia (86). This is exemplified by inactivation of the Fraser syndrome gene, Fraser extracellular matrix complex subunit 1 (Fras1) (87, 88), integrin alpha 8 (Itga8) (89), and nidogens 1 and 2 (simultaneously) (90), which all cause incompletely penetrant kidney development failure.

\section{Mutations identified in human renal aplasia}

Sequencing of human CAKUT samples has confirmed that several genes identified as essential regulators of early kidney induction in mice are also mutated in human patients (91). As in mice, mutations in transcription factors HOX11 (92), PAX8 (93), SALL1 (94), WT1 (95), as well as in signaling pathways such as FGFR1 (96) (syndromic; renal agenesis in Kallman syndrome), FGF20 (79) GREM1 (97), and RET (94, 98), cause renal aplasia in humans. Moreover, FRAS1 (88) (syndromic; renal agenesis in Fraser syndrome) and Fras1-related extracellular matrix protein 2 (FREM2) (92, 99), as well as integrin alpha 8 (ITGA8) (100) mutations are associated with renal aplasia in CAKUT patients. Other genes not previously identified in animal models cause not only renal aplasia but also other kidney defects in humans. These include WAP four-disulfide core domain $18(101,102)$ (also known as KAL1), cell division cycle 5 like (CDC5L) (94), establishment of sister chromatid cohesion N-acetyltransferase 2 (ESCO2) (103) (syndromic; included in the Roberts syndrome spectrum), and dual serine/threonine and tyrosine protein kinase (DSTYK), which is a positive regulator of extracellular signal regulated kinase (ERK) that co-localizes with FGF receptors in the UB and MM and may perturb FGF signaling (104).

The vast majority of CAKUT-causing gene mutations are heterozygous. In general, homozygous mutations of key regulators may result in early miscarriage or abortion of the fetus rather than cause a disease syndrome or single organ defect. It is also possible that multiplied members of a gene families in humans can substitute for the loss of a single member (redundancy), or that modifier aberrations in other genes are required for CAKUT manifestation.

\section{Mutations in human renal hypoplasia and hypodysplasia}

Many genes causing renal aplasia in mice are not associated with renal aplasia in human, but rather when mutated in human, cause an explicitly less severe renal phenotype, such as hypoplasia (small kidney with normal morphology) or hypodysplasia (small kidney with abnormal differentiation). Such genes include EYA1 (94, 105), OSR1 (106), PAX2 $(94,107)$, SALL1 $(94,105)$, RET 
(108) and GRFa1 (109). Mutations in additional genes associated with human renal hypoplasia or hypodysplasia are transcription factors hepatocyte nuclear factor $1 \mathrm{~B}(94,110)(H N F 1 B)$ and sine oculis-related homeobox 2 (111) (SIX2), signaling molecules uroplakin 3A (112) (UPK3A), WNT4 (94), and BMP4 (113); and planar polarity gene EGF LAG seven-pass G-type receptor 1 (CELSR1) (114). It is likely that renal hypoplasia is an underdiagnosed sub-category of CAKUT as patients with hypoplastic kidneys, which mostly function normally and do not develop renal disease, remain unrecognized unless the individual does develop related complications like hypertension. This is different in genetically modified experimental models, which are carefully analyzed for renal defects both during embryogenesis and adulthood (115).

\section{Mouse models of hypo(dys)plasia}

A huge number of mouse mutants display either hypoplasia only or in combination with dysplasia. Due to the scope of this chapter, we focus on genes that associate with human CAKUT genes and their signaling cascades.

Mutations in transcription factors HNF1B and PAX2 are the most common causes of renal hypodysplasia in children $(105,116)$. This is reflected in mouse where the full inactivation of Pax 2 causes aplasia, while its heterozygous deletion alone causes no phenotype, but simultaneous compound heterozygosity for Hnf1b results in renal hypodysplasia (117). Homozygous deletion of Hnf1b on the other hand results in embryonic lethality before gastrulation (118). However, tetraploid embryo complementation and tissue-specific inactivation studies have demonstrated the requirement of $H n f 1 b$ for at least growth and integrity of the UB, early nephrogenesis, differentiation of the proximal nephron segment, and differentiation of the renal medulla (119-121). In addition, deletion of transcription factor Etv4 or -5 results in renal hypodysplasia though their distinct and joint tissue-specific functions are not fully revealed $(16,69)$. Also Sox8 and -9 act together downstream of GDNF/RET signaling, and their inactivation in the developing kidney causes renal defects varying from aplasia to mild hypoplasia (122). Interestingly, SOX9 appears to mediate important responses to acute kidney injury, at least as identified in mouse with ischemia reperfusion-induced injury $(123,124)$.

Renal hypodysplasia in mice without $B$ cell leukemia/lymphoma $2(B c / 2)$ factor is caused by an unusual mechanism as its inactivation allows normal renal differentiation until embryonic day 13, after which the nephron progenitors disappear due to increased apoptosis (125). Similarly, inactivation of Six 2 causes renal hypoplasia due to early loss of nephron progenitors, but in this case through their premature differentiation and exhaustion at mid-gestation $(22,126)$.

Vitamin A deficiency has been experimentally shown to control nephron number as mice with inactivated Raldh1a2 (also known as Aldh1a1) have small kidneys due to a UB branching defect (127). Genetic experiments have also revealed strong involvement of BMP- and WNT signaling in guiding embryonic kidney growth and differentiation (128-131). The involvement of BMP signaling is exemplified by deletion of $B m p 7$, which results in severe renal hypoplasia with virtually no glomeruli due to a defect in survival of nephron progenitors (132-135). Further studies have shown redundant functions for BMP4 and -7; genetic substitution of $B m p 7$ by $B m p 4$ in mice rescues renal defects(136). Furthermore, deletion of either ligand in a Grem1-null background, which causes renal aplasia on its own (75), restores normal kidney differentiation (137). High redundancy in BMP signaling, as suggested by ligand deletions, is also obvious at the receptor level because deletion of BMP receptors has either no impact on kidney development or results in hypodysplasia in the renal medulla $(B m p r 1 a)(128,138)$. The phosphatase Dullard, a recently identified negative BMP signaling 
modulator, on the other hand is required for maintenance of postnatal nephrons (139). Deletion of another BMP signaling modulator, Crossveinless2, which likely amplifies signal strength, results in multi-organ defects including renal hypoplasia due to impaired nephrogenesis $(140,141)$. Signaling downstream of BMP receptors phosphorylates Smad1/5/8 and/or induces TAK1, which can activate p38/mitogen-activated protein kinase (MAPK), JNK/c-Jun, and NF-kB cascades. Inactivation of either Tak1 or Jun tissue-specifically in nephron progenitors causes their premature depletion and results in mild renal hypoplasia (142).

The importance of WNT signaling for renal differentiation, and especially for nephron induction, was originally revealed by classical induction experiments performed with isolated mouse $\mathrm{MM}$ in tissue culture. Initially, these experiments showed that in the absence of a heterologous inducer, such as spinal cord, the MM underwent rapid apoptosis and failed to survive $(1,143)$. Soon it was discovered that embryonic spinal cord is rich in WNT proteins. When WNT proteins were expressed in cultured cells and placed in contact with MM, they also induced tubulogenesis (144). Inactivation of Wnt4 in mouse verified the essential function of WNT activation as a nephron inducer, as nephrogenesis failed to progress beyond the pretubular aggregate stage in this model (145). Consequent tissue-specific deletion (146) and activation (147) of $\beta$-catenin in the MM verified the requirement for the canonical WNT pathway. Similarly, $\beta$-catenin is required for keeping the UB actively branching as shown by the loss- $(84,148)$ and gain-of-function $(149)$ strategies that both result in renal hypoplasia due to defects in maintaining the balance of self-renewal and differentiation.

As shown by deletion of receptor tyrosine kinases Ret or Fgf receptors and their ligands, these signaling pathways are essential for initiation of kidney development, and when fully inactivated, most often cause renal aplasia (150). However, mutations introduced in the specific tyrosine domains of Ret responsible for the distinct intracellular pathway activation cause phenotypes varying from mild hypoplasia to severe hypodysplasia (151-154). These models together with chemical inhibition experiments in cultured mouse kidney explants have demonstrated that MAPK/ERK, PI3K/AKT, and PLCY cascades mediate the downstream effects of RTK signaling in developing kidneys $(12,155,156)$. Furthermore, tissue-specific inactivation of tyrosine phosphatase Shp2, which functions downstream of RTK and hormone receptors, as well as MAPK/ERK in the UB, results in renal hypodysplasia $(157,158)$. The latter model also revealed a specific requirement for MAPK/ERK activity in kidney growth where it promotes UB arborization via novel branch formation (158). Inactivation of MAPK/ERK activity in the MM, on the other hand, results in slightly less severe renal hypodysplasia, and demonstrates that the MAPK/ERK pathway maintains nephron progenitors while also being crucial for their normal differentiation beyond the comma-shaped body stage (23). UB-specific genetic disruption of another intracellular cascade, the PI3K/AKT pathway, suggests that it is important for shaping the UB branching pattern (159).

Hippo signaling regulates the growth and size of organs in insects and mammals, and has recently been implicated in the guidance of kidney morphogenesis (160). In mammals, the Hippo pathway involves the kinases MST1/2 and LATS1/2, and their functions are mediated by the transcriptional co-activators YAP and TAZ. Genetic studies have revealed that Lats1 and -2 are critically required for UB branching as their tissue-specific deletion results in renal aplasia (161). Interestingly, experiments with the mutant UB also revealed an unexpected interaction between Nf2 (also known as Merlin) and Hippo signaling, as genetic overexpression of either Yap or Taz fully rescues severe renal hypodysplasia in the kidneys with UB-specific $N f 2$ deletion (161). In the MM, Lats1 and -2 together promote differentiation of nephron progenitors (162), while Yap and Taz 
appear to have distinct functions in the developing mouse kidney. Similarly to the upstream kinases, Yap promotes nephrogenesis (163) while Taz is needed for prevention of cyst formation $(164,165)$.

Cell polarity is an important feature of the functional kidney. Inactivation of either of the planar cell polarity genes Celsr1 (114) or Vangl1 (166) causes renal hypodysplasia in mice as both genes are required for normal growth and branch patterning in the developing kidney. Tissuespecific deletion of structural proteins, such as actin remodeling factors destrin (Dstn) and cofilin (Cfl1) (167), and adhesion proteins like p120 (168), also serve as excellent models of renal hypodysplasia. Instead of halting organogenesis at its earliest stage, these models allow formation of the UB, some degree of branching, and induction of nephrogenesis, thus enabling experimentation that facilitates understanding of kidney differentiation at the cellular level.

\section{Ectopia}

The kidneys are normally located in the retroperitoneal space (behind the abdominal cavity) at the level of the stomach. The most common ectopic location of the kidney is in the pelvis. Ectopia can be associated with vesicourinary reflux and mislocation of the ureteric opening in the wall of the urinary bladder, where the normal location is close to the urethral orifice in the so-called triangle area of the urinary bladder.

\section{Mouse models of ectopia}

Experimental models of ectopia are rare despite its relatively common prevalence in humans. The etiology of ectopia was originally hypothesized by Mackie and Stephens (1975) to derive from aberrant initial ureteric budding site (169) and has since been proven by e.g. genetic reduction of Bmp4 dosage, which results in hydroureters and ectopia of the ureterovesical orifice (170). Similarly, defective RET signaling results in ectopic connection of the ureter to bladder (46, 171-173), and recent findings show that dosage of Gdnf critically regulates the initial UB budding site and width. As shown in recent study, GDNF positively regulates self-renewal of collecting duct progenitors, which in the genetic excess of Gdnf expand abnormally resulting in failure of UB trunk elongation $(174,175)$, Consequently, a phenotype very much resembling human pelvic kidney develops due to short ureter length caused by imbalanced progenitor self-renewal and differentiation. Kidney ectopia may also rise through a different mechanism involving deficiency in retinoic acid receptors (176) and defects in the differentiation of smooth muscle cells around the ureter itself as seen in mice with deleted transcription factors Sox9 (177), -11 (178), or Tbx18 (179) that all have abnormally positioned kidneys.

\section{Mutations identified in human renal ectopia}

Aberrations in SOX11 (178) and TBX18 (180) have been identified in patients with varying renal defects that include posterior urethral valves, ureteropelvic junction obstructions, ureterovesical junction obstruction, and vesicoureteral reflux. Rare mutations in genes encoding RET and GFRa1 were also identified in CAKUT fetuses and patients with urinary tract malformations, while only one patient with combined unilateral agenesis and ectopic kidney so far has been identified with a GDNF-only mutation $(109,181)$. 


\section{Ureteral duplication}

Ureteral duplication is a common form of CAKUT. It can be complete, resulting in two pelvises and two separate ureters in one kidney. Alternatively, one ureter can be divided into two branches with two distinct orifices in the urinary bladder. Ureteral duplication is associated with many complications of which vesicoureteral reflux and ureteropelvic junction obstruction are most often found in patients with incomplete duplication. Complete duplication, which most often associates with vesicoureteral reflux, ectopic ureterocele, or ectopic ureteral insertion, shows a gender bias as all of the associated complications are more common in girls than in boys (182).

\section{Mouse models of ureteral duplication}

Supernumerary ureteric buds are experimentally promoted in mouse by transgenic GDNF overexpression (183) or in kidney culture by GDNF-releasing beads (184). Inactivation of genes that restrict Gdnf expression (Robo2/Slit2 $(185,186)$, FoxC (187)) or regulate GDNF/RET signaling activity (Sprouty1 $(188,189)$ ) cause extra UB formation and exhibit defects commonly associated with duplicated ureters. Interestingly, endogenous overexpression of Gdnf by disruption of its 5' untranslated region does not induce extra ureteric budding even though both mRNA and protein levels are significantly increased (174). Quite illogically, inactivating mutations in the RET docking site responsible for PLCY activation also cause supernumerary budding similar to that seen with exogenous GDNF $(151,184)$. These somewhat confusing results from different genetic mouse models of the same signaling pathway can be interpreted in a way that a single UB formation is an absolutely essential requirement for normal renal morphogenesis. Thus, multiple molecular mechanisms, several different genes, and many pathways at distinct levels are engaged to secure the single UB formation. In support of this are the findings demonstrating that simultaneous inactivation of Spry1 and Gdnf or Ret allows functional kidney formation, but additional deletion of a single allele of Fgf8 results in failure to form kidneys $(190,191)$. Furthermore, exogenous application of FGF together with activin $A$ induces supernumerary ureter budding in cultured kidneys even in the absence of GDNF/RET signaling (192).

Disruption of other genes not directly linked to GDNF or FGF signaling also cause ureteral duplication. Deletion of leucine zipper putative tumor suppressor 2 (Lzts2), which modulates transcription and regulates cell cycle, results in ureteral duplication due to ectopic UB formation (193). Genetic experiments have shown that BMP4 is an essential molecule assuring that a single UB forms as mice heterozygous for Bmp4 loss show multiple UBs (111). Conditional deletion of transcription factor Islet1 resulted in reduced Bmp4 expression and multiple UBs mimicking the Bmp4 heterozygote phenotype (194).

\section{Mutations identified in human ureteral duplications}

Roughly the same genes are involved in ureteral duplication as in renal ectopia. In addition to those mentioned previously for ectopic kidneys, mutations in BMP4 (111, 195), SIX2 (111), SOX17 (196), glypican 1 (GPC1) (197), and variations in ROBO2 associate with vesicoureteral reflux and/or duplex kidneys (198-200).

Horseshoe kidneys/renal fusion

Fusion of the lower parts of two kidneys results in a horseshoe kidney that is commonly seen in trisomy 18 (also known as Edward's syndrome, see Figure 5.3) and Turner syndrome patients. Its 
incidence is likewise slightly increased in trisomy 21 (Down's syndrome). Horseshoe kidneys furthermore occur sporadically without any associated syndromes or functional disturbances. Etiology of this anomaly derives from abnormal migration of nephrogenic cells across the primitive streak and general structural changes caused by midline fusion, flexion/rotation of the caudal spine, and narrowed arterial forks during migration. Fusion typically occurs between weeks four and six of human development. The rare late fusions occur through fibrous isthmus rather than renal parenchyma (201).

\section{Mouse models of horseshoe kidney}

Disruption of functional Sonic hedgehog (Shh) signaling causes midline defects and inactivation of Shh specifically in the notochord and the floor plate causes fusion of the kidneys (202). Similarly, horseshoe kidneys are seen in mice with mild aberrations in retinoic acid signaling, such as those caused by deletion of Cyp26a, which is required for the inactivation of retinoic acid $(203,204)$. Deletion of transcription factor FoxD1 results in a range of renal defects, which include fusion of maturing kidneys that remain in the pelvic position (205). A follow-up study focused on analyzing causes of kidney fusion in Foxd1 mutant kidneys. This revealed the presence of ectopic cell types in the renal capsule, which leads to its maturation defect and pelvic horseshoe kidneys (206).

\section{Mutations identified in human horseshoe kidneys}

Regardless of familial clustering of horseshoe kidney in certain cases, its genetic causes remain largely unidentified. Potential deleterious variations have been identified in Dachsous cadherin-related 2 (DCHS2) and leucine-rich repeat-containing G protein-coupled receptor 4 (LGR4) (207). Genome wide association studies identified CYP26A together with CYP24A and BMP4 as potential disease-causing mutations in CAKUT, but their association specifically to horseshoe kidney is not reported (208). Thus, according to current knowledge, large chromosomal aberrations rather than single gene mutations associate with fused kidney in humans.

\section{Renal multi-cystic dysplasia and polycystic kidney disease}

Renal multi-cystic dysplasia is characterized by variable numbers of cysts in either one or both kidneys or only in a segment of a kidney (Figure 5.3). The pathogenesis is not yet completely resolved, but experimental studies with rabbits have shown that ligation of the ureter causes similar cyst formation and differentiation defect (209).

There are two types of polycystic kidney diseases (PKD), the infantile (early onset recessive) and adult (late onset dominant) polycystic kidney diseases. Infantile PKD manifests at birth or soon after and is associated with high mortality if renal transplantation is not performed. Adult PKD manifests at any age of adulthood and has a less severe outcome. These two most common forms of PKD show autosomal recessive and autosomal dominant inheritance, respectively. The later onset autosomal dominant PKD is one of the most common genetic diseases with an incidence of 1:500 1:1000, while the early onset autosomal recessive form is much rarer (210). 


\section{Mutations identified in humans with renal cysts}

Although renal multi-cystic dysplasia is less abundant in humans than PKD, mutations in BicC family RNA binding protein 1 (BICC1) $(97,211), C D C 5 L(212)$, dachshund family transcription factor 1 (DACH1) (213), HNF1B (110, 214, 215), and upstream transcription factor 2 (USF2) (216) all associate with cystic dysplasia. Autosomal dominant PKD mainly derives from mutations in polycystin (PKD) genes (217). The majority of the mutations ( $85 \%)$ are in PKD1, which encodes a large receptor-like protein (polycystin 1) that interacts with PKD2 gene product polycystin 2 (218). Mutations in PKD2 account for $\sim 15 \%$ of autosomal dominant PKD cases, while recently a new causative gene, glucosidase II alpha subunit (GANAB), was identified in rare patients who are negative for PKD1 and -2 mutations $(217,219)$. Autosomal recessive PKD was long considered a genetically homogenous disease. Mutations in $P K H D 1$, which encodes fibrocystin localizing to the primary cilia to modulate Shh and Wnt activities, cause the majority of these cases (220). Aberrations in yet another ciliary protein encoded by DZIP1L (221), were recently identified in patients with moderate clinical symptoms of autosomal recessive PKD, affecting also liver function. Mutated HNF1B in some patients also causes cystic kidneys, while its aberrations are associated with hypodysplasia and diabetes syndrome $(110,222)$.

\section{Mouse models of cystic kidney and polycystic kidney disease}

The mouse models of polycystic kidney disease have revealed that defects in genes encoding primary cilia-located proteins are responsible for abnormal cellular proliferation and fluid accumulation that jointly lead to the formation of numerous cysts in renal tubules. Deletion of either Pkd1 (223) or Pkd2 $(224,225)$ best models the human PKD, while inactivation of Pkhd1 (226) in rats and inhibition of ciliogenesis by loss of Kif3a in mouse (227) also result in a phenotype very reminiscent of human PKD. In mouse models of inactivated glucosidase $\| / B$ and Sec63p, which exhibit mild kidney cysts on their own, reduced $P k d 1$ sensitizes kidneys for cystogenesis further highlighting its essential role in PKD pathogenesis (228).

Genetic disruption of genes regulating ureter morphogenesis and/or connection to the bladder may cause renal multicystic dysplasia. As examples, atypical cadherin Fat4 (229), its interacting partner four-jointed box 1 (Fjx1) (229), cadherin-related dachsous genes (Dchs1 and -2) $(229,230)$, and other adhesion-related molecules like Dlg5, which is required for the delivery of adhesome complex components(231), Frem2 (99) and Glc3 (232), all cause cystic kidneys when inactivated in mice. Also, Lzts2 mutant embryos, which exhibit duplex ureters, show other defects such as hydroureters and hydronephrosis accompanied with renal multicystic dysplasia (193).

\section{Congenital nephrosis}

Congenital nephrosis is a condition under which the glomeruli leak protein into the urine during pregnancy. It is caused by the defects of the glomerular filtration barrier, which is composed of the slit diaphragm connecting adjacent podocyte foot processes, the glomerular basement membrane, and the fenestrated endothelium of the capillary loops. Congenital nephrosis is characterized by excess of amniotic fluid or polyhydramnion and enlarged placenta, which weighs more than 50 percent of the fetal weight. Renal symptoms are typically caused by impaired podocyte physiology that derives from mutations in gene encoding proteins of the slit diaphragm (233). The congenital nephrotic syndrome is a rare form of nephrosis, which is highly enriched in the Finnish population with occasional cases reported all over the world (234). 


\section{Mutations causing congenital nephrotic syndrome in humans}

Kestilä et al identified the causative mutation for congenital nephrotic syndrome of the Finnish type in a gene encoding the slit diaphragm protein nephrin (NPHS1) (235). Originally, two founder mutations were identified but since then more than 20 additional mutations have been shown to cause this syndrome. Although approximately $98 \%$ of Finnish and $38-90 \%$ of non-Finnish congenital nephrotic syndrome patients carry mutations in NPHS1 (236-238), mutations in other genes encoding podocin (NPHS2), phospholipase C epsilon-1 (PLCE1), WT1, and laminin beta 2 (LAMB2) have been identified. Genetic diagnosis is important for designing patient treatment plans, as steroid-resistant nephrotic syndrome typically derives from the defects in NPHS2 $(238,239)$. Moreover, mutations in PLCE1 $(240)$ and WT1 $(238,241)$, like in FAT1 (242), cause a more diffuse mesangial sclerosis-type of phenotype while $\operatorname{LAMB2}(238,243)$ mutations give rise to microcoria. Finally, mutations in genes encoding collagen IV (COL4A3, -A4 and -A5), which is the major form of collagen present in the glomerulus, also cause congenital nephrosis due to characteristic abnormalities in the glomerular basement membrane (244).

\section{Mouse models of congenital nephrotic syndrome}

Characteristic of congenital nephrotic syndrome studies is that the human mutations were often identified prior to the generation of their genetic animal models. The mouse models where the major syndrome causing genes, Nphs1 (245), -2 (246), Lamb2 (247, 248), or Col4a3 (249) were knocked out recapitulate the renal symptoms quite well and have been valuable tools for understanding the cellular and molecular mechanisms of these pathologies. Manipulation of other genes encoding slit diaphragm components, like inactivation of CD2-associated protein (Cd2ap) (250), often compromises podocyte function and may recapitulate specific features of congenital nephrosis (251).

\section{Nephroblastomatosis (nephrogenic rests) and Wilms' tumor}

Nephroblastomatosis is a condition where islands of the nephrogenic blastema remain in the kidney postnatally (Figure 5.4). These islands are also called nephrogenic rests and may reside either intra- or perilobarly. Intralobar rests arise early in renal development, while perilobar rests are in the renal cortex, which is the active differentiating zone. They either spontaneously regress or progress and finally become malignant tumors called nephroblastomas, also known as Wilms' tumors (Figure 5.5). It is impossible to distinguish between regressive and progressive nephoblastoma by any morphological or immunohistochemical means.

\section{Mutations and syndromes associated with Wilms' tumor in humans}

Despite being the most common pediatric renal cancer, the prevalence of Wilms' tumor is generally low (1:10,000 children). Its incidence is significantly increased in syndromes like Wilms' tumor, aniridia, genitourinary anomalies, and mental retardation (WAGR), Beckwith-Wiedemann (BWS), hemihypertrophy, Denys-Drash, and Perlman. Hemihypertrophy is a condition where the left and right sides of the body show clear growth differences, while Beckwith-Wiedemann syndrome is a congenital overgrowth syndrome, where the organs are bigger than expected for the age of the child. Tuberous sclerosis, a highly variable disorder typically diagnosed soon after birth, associates with the development of benign tumors in different organs, including the kidneys (252). Although 
otherwise harmless, the benign tumors may interfere with the normal function of the affected organ. Tuberous sclerosis causes cystic kidneys in approximately $20-30 \%$ of individuals, but their renal function is rarely compromised.

The most commonly altered genetic locus causing Wilms' tumor is the one disturbing insulinlike growth factor 2 (IGF2), which is one of the imprinted genes and normally expressed only when paternally derived. In approximately $70 \%$ of all Wilms' tumors, biallelic IGF2 expression results in tumorigenesis (253). Genetic analysis of WAGR and Denys-Drash revealed an association of germline mutations in WT1, and later, somatic mutations were identified in many Wilms' tumors (254). These somatic-inactivating mutations associate with intralobar nephrotic rests and thus could be responsible for early defects in renal differentiation leading to tumor development (255). Other mutations have been identified in the $\beta$-catenin encoding CTNNB1 gene (256), often together with a WT1 mutation (257), and in Wilms' tumor on chromosome X (WTX) gene (258), which couples WT1 to $\beta$-catenin as it negatively regulates Wnt signaling and participates in the control of WT1 transcription $(259,260)$. Also, mutations in the microRNA-processing genes that derepress IGF2 levels via its regulator PLAG1 have been identified. This further underlines the importance of the IGF2 signaling dosage in tissue homeostasis during kidney differentiation (261). Interestingly, a longsought Wilms' tumor cancer stem cell, double positive for NCAM1 and RALDH1, was identified (262). This may help the future aims of revealing the relationship between cancer stem cells and other stem cell types in the kidney, namely nephron and collecting ductal progenitors.

\section{Mouse models of nephroblastomatosis and Wilms' tumor}

The genes associated with Wilms' tumor in humans are required for the early steps of embryogenesis and renal development. $W t 1$ deletion in mouse results in complete failure of kidney induction $(55,263)$. Ctnnb1 expressed by the UB is required for branching morphogenesis and in the MM for normal nephrogenesis $(84,149)$. Thus, the proteins encoded by these genes are crucial for normal organogenesis, and their null mutant mice fail to serve as models for nephrogenic rests or Wilms' tumor. Mosaic inactivation of Wt 1 together with constantly increased Igf2 rescues mice from perinatal death caused by complete inactivation of $W t 1$ and results in nephron progenitor-derived renal tumors that resemble a certain subtype of human tumors $(264,265)$. Moreover, inactivation of $W t 1$ at different nephron differentiation stages and comparison of the resulting RNA signature in mutant kidneys with different subtypes of human Wilms' tumor revealed a correlation supporting the view that the disturbed nephrogenesis is an important contributor of tumorigenesis (263). Interestingly, kidneys in the mouse model of excess endogenous Gdnf (174) show structures reminiscent of perilobar nephrogenic rests, but these disappear by spontaneous differentiation during early postnatal life. To our knowledge, the field still lacks a proper genetic model of pediatric renal cancer that could serve as a preclinical model and facilitate understanding of the mechanisms of tumor growth and the role of kidney cancer stem cells.

\section{Renal disease in syndromes}

In addition to the syndromes mentioned in the previous sections, Alagille, Branchio-otorenal (BOR), Fraser, Kallmann, Meckel, Pallister-Hall, renal coloboma, and Townes Brocks syndromes are all associated with renal anomalies. 
Alagille syndrome is caused by defective Notch signaling. It is characterized by defects in the liver, heart, skeleton, eyes, and kidneys. The kidneys are most often affected in individuals with NOTCH2 mutations, and include hypodysplasia and cysts, which compromise renal function (266). The majority of Alagille patients, though, have mutations in NOTCH ligand Jagged1 (JAG1). Despite a suggested function in the maintenance of UB tip identity, very little is known about the function of Jag1 in renal differentiation (267). Inactivation of Notch2 in mouse recapitulates renal defects and has revealed the importance of this signaling pathway in fate determination of distinct nephron segments $(268,269)$.

Branchio-oto-renal syndrome is an inherited autosomal dominant disorder, which according to its name, exhibits defects in a variety of organs, including a spectrum of kidney defects ranging from mild to very severe (aplasia). The causative mutations of BOR have been identified in EYA1, SIX5, and SIX1 genes, along with SALL1 mutations, which cause a BOR-related disorder, Townes Brocks syndrome. See section Aplasia and hypoplasia for details of these genes and their functions.

Fraser syndrome The spectrum of renal defects in Fraser syndrome include hypo(dys)plasia and uni- or bilateral agenesis. Human mutations have been identified in FRAS1 and FREM2, which were discussed previously (Aplasia and hypoplasia), as well as in glutamate receptor-interacting protein 1 (GRIP1) gene $(270,271)$.

Kallmann syndrome The most typical feature of Kallmann syndrome is delayed or absence of sexual development. The renal manifestation is relatively rare in Kallmann patients, but it may appear as the absence of one kidney. Kallmann syndrome mutations have been identified in FGFR1, FGF8 (discussed earlier), WAP four-disulfide core domain 18 (WFDC18, also known as ANOS1 and KAL1) (272), SOX10 (273), and semaphorin SEMA3A (274).

Meckel syndrome (also known as Grubel-Meckel syndrome) consists of a posterior encephalocele, where the dorsal parts of the brain expand backwards and are only covered by skin. The patients also show postaxial polydactyly (duplicated little finger and/or toe) and cystic renal disease that somewhat morphologically resembles polycystic renal disease with liver cysts.

Meckel syndrome, similar to congenital nephrosis of the Finnish type, is greatly enriched in the Finnish population due to the founder effect, which enriches disease inheritance and manifestation in isolated populations typically due to a major mutation distribution among small number of individuals living within the population. Identification of mutations in Meckel syndrome, type 1 (MKS1) gene, encoding a protein required for the normal function of primary cilia (275), was a landmark for understanding the cellular mechanisms leading to Meckel syndrome and other ciliopathies. Since then, mutations in at least 12 more genes have been associated with Meckel syndrome (276). Despite an obvious genetic heterogeneity, the major Meckel syndrome-causing mutations are in MKS1, MKS3/TMEM67, and MKS6/CC2D2A.

Pallister-Hall syndrome derives from defects in Hedgehog signaling manifested as mutations in GLI3 effector gene (277). The many-fold abnormalities in Pallister-Hall patients are often not lifethreatening, unlike e.g. deletion of Gli3 in mice, which causes renal aplasia (278). Associated kidney abnormalities of Pallister-Hall syndrome are rare, but typically manifest as renal dysplasia.

Renal coloboma syndrome The characteristic defects of renal coloboma syndrome, also known as papillorenal syndrome, include optic nerve dysplasia and renal hypodysplasia. It is a rare autosomal dominant disorder, which is caused by mutations in PAX2 (279). Defects caused by Pax2 inactivation in mouse have been discussed in the Aplasia and hypoplasia section above. 


\section{Conclusions}

Mouse models have greatly facilitated our understanding of renal differentiation and its molecular regulation. The benefit for genetics and diagnosis of congenital kidney anomalies is also obvious. However, the majority of human CAKUT cases are idiopathic, and their causes remain unknown despite the strong familiar aggregation in approximated $15 \%$ of patients $(91,280)$. In addition to genetic causes, environmental and epigenetic factors are also involved, while only approximately 5-20\% of CAKUT are considered monogenic disease (281-283). The two challenges in modeling congenital kidney anomalies in experimental animals are the lack of knowledge of causative gene mutation and use of inappropriate strategy to mimic given human disease in mouse. The first of these may derive from the fact that large portions of genome (GC-rich and other repetitive or difficult-to-reach regions) are not covered in whole-genome sequencing experiments. Potential aberrations in these non-coding genomic regions may be considered epigenetic causes of CAKUT, and they remain unexplored until better knowledge and methodologies are available for their exploration. The second challenge refers to the fact that mouse models of CAKUT so far have largely been made by complete inactivation of the entire gene. The next task for the scientific community is to utilize CRISPR/CAS9 methodology to mimic specific human CAKUT mutations in mice, a strategy which is expected to much better phenocopy the given anomaly it associates with in human patients.

\section{Acknowledgements}

We would like to thank Dr. Carlton Bates, Dr. Cristina Cebrian and Dr. Peter Hohenstein for insightful discussions, and MSc Kristen Kurtzeborn for reviewing the manuscript for English language.

\section{References}

1. Saxen L. Failure to demonstrate tubule induction in a heterologous mesenchyme. Devel Biol. 1970;23:511-23.

2. Wartiovaara J, Nordling S, Lehtonen E, Saxen L. Transfilter induction of kidney tubules: correlation with cytoplasmic penetration into Nucleopore filters. J Embryol Exp Morphol. 1974;31:667-82.

3. Saxen L. Organogenesis of the Kidney. Cambridge: Cambridge University Press; 1987.

4. Takasato M, Little MH. The origin of the mammalian kidney: implications for recreating the kidney in vitro. Development. 2015;142(11):1937-47.

5. Taguchi A, Kaku Y, Ohmori T, Sharmin S, Ogawa M, Sasaki H, et al. Redefining the in vivo origin of metanephric nephron progenitors enables generation of complex kidney structures from pluripotent stem cells. Cell Stem Cell. 2014;14(1):53-67.

6. Davidson AJ. Mouse kidney development. StemBook. Cambridge (MA)2008.

7. Davidson AJ, Lewis P, Przepiorski A, Sander V. Turning mesoderm into kidney. Semin Cell Dev Biol. 2018.

8. de Bruijn MF, Speck NA, Peeters MC, Dzierzak E. Definitive hematopoietic stem cells first develop within the major arterial regions of the mouse embryo. EMBO J. 2000;19(11):2465-74.

9. Sainio K, Hellstedt P, Kreidberg JA, Saxen L, Sariola H. Differential regulation of two sets of mesonephric tubules by WT-1. Development. 1997;124(7):1293-9. 
10. Woolf AS, Winyard, P. J. D., Hermanns, M. M., Welham, S. J. M. Maldevelopment of the Human Kidney and Lower Urinary Tract: An overview. In: Vize PD, Woolf, A. S., Bard, J. B. L, editor. The Kidney: From normal development to Congenital Disease. London: Academic Press; 2003. p. 377

11. Costantini F. Genetic controls and cellular behaviors in branching morphogenesis of the renal collecting system. Wiley interdisciplinary reviews Developmental biology. 2012;1(5):693-713.

12. Watanabe T, Costantini F. Real-time analysis of ureteric bud branching morphogenesis in vitro. Dev Biol. 2004;271(1):98-108.

13. Short KM, Combes AN, Lefevre J, Ju AL, Georgas KM, Lamberton T, et al. Global quantification of tissue dynamics in the developing mouse kidney. Dev Cell. 2014;29(2):188-202.

14. Shakya R, Watanabe T, Costantini F. The role of GDNF/Ret signaling in ureteric bud cell fate and branching morphogenesis. Dev Cell. 2005;8(1):65-74.

15. Chi X, Michos O, Shakya R, Riccio P, Enomoto H, Licht JD, et al. Ret-dependent cell rearrangements in the Wolffian duct epithelium initiate ureteric bud morphogenesis. Dev Cell. 2009;17(2):199-209.

16. Kuure S, Chi X, Lu B, Costantini F. The transcription factors Etv4 and Etv5 mediate formation of the ureteric bud tip domain during kidney development. Development. 2010;137(12):1975-9.

17. Riccio P, Cebrian C, Zong H, Hippenmeyer S, Costantini F. Ret and Etv4 Promote Directed Movements of Progenitor Cells during Renal Branching Morphogenesis. PLoS Biol. 2016;14(2):e1002382.

18. Potter SS. Single-cell RNA sequencing for the study of development, physiology and disease. Nat Rev Nephrol. 2018;14(8):479-92.

19. Lignell A, Kerosuo L, Streichan SJ, Cai L, Bronner ME. Identification of a neural crest stem cell niche by Spatial Genomic Analysis. Nat Commun. 2017;8(1):1830.

20. Cebrian C, Borodo K, Charles N, Herzlinger DA. Morphometric index of the developing murine kidney. Dev Dyn. 2004;231(3):601-8.

21. Nagalakshmi VK, Yu J. The ureteric bud epithelium: morphogenesis and roles in metanephric kidney patterning. Mol Reprod Dev. 2015;82(3):151-66.

22. Kobayashi A, Valerius MT, Mugford JW, Carroll TJ, Self M, Oliver G, et al. Six2 defines and regulates a multipotent self-renewing nephron progenitor population throughout mammalian kidney development. Cell Stem Cell. 2008;3(2):169-81.

23. Ihermann-Hella A, Hirashima T, Kupari J, Kurtzeborn K, Li H, Kwon HN, et al. Dynamic MAPK/ERK Activity Sustains Nephron Progenitors through Niche Regulation and Primes Precursors for Differentiation. Stem Cell Reports. 2018.

24. Sariola H. Nephron induction revisited: from caps to condensates. Curr Opin Nephrol Hypertens. 2002;11(1):17-21.

25. Kurtzeborn K, Cebrian, C. and Kuure, S. Regulation of renal differentiation by trophic factors. Frontiers in Physiology. 2018; https://doi.org/10.3389/fphys.2018.01588.

26. O'Brien LL. Nephron progenitor cell commitment: Striking the right balance. Semin Cell Dev Biol. 2018.

27. Costantini F, Kopan R. Patterning a complex organ: branching morphogenesis and nephron segmentation in kidney development. Dev Cell. 2010;18(5):698-712.

28. Hartman HA, Lai HL, Patterson LT. Cessation of renal morphogenesis in mice. Dev Biol. 2007;310(2):379-87.

29. Cebrian C, Asai N, D'Agati V, Costantini F. The number of fetal nephron progenitor cells limits ureteric branching and adult nephron endowment. Cell reports. 2014;7(1):127-37.

30. Beck JA, Lloyd S, Hafezparast M, Lennon-Pierce M, Eppig JT, Festing MF, et al. Genealogies of mouse inbred strains. Nat Genet. 2000;24(1):23-5.

31. Rabe M, Schaefer F. Non-Transgenic Mouse Models of Kidney Disease. Nephron. 2016;133(1):53-61. 
32. Wang Q, Hummler E, Nussberger J, Clement S, Gabbiani G, Brunner HR, et al. Blood pressure, cardiac, and renal responses to salt and deoxycorticosterone acetate in mice: role of Renin genes. J Am Soc Nephrol. 2002;13(6):1509-16.

33. Kuure S, Vuolteenaho R, Vainio S. Kidney morphogenesis: cellular and molecular regulation. Mech Dev. 2000;92(1):31-45.

34. Anders H, Schlondorff D. Murine models of renal disease: possibilities and problems in studies using mutant mice. Exp Nephrol. 2000;8(4-5):181-93.

35. Lyon MF, Rastan S, Brown SDM, editors. Genetic Variants and Strains of the Laboratory Mouse. 3rd ed. Oxford: Oxford University Press; 1996.

36. Schieren G, Pey R, Bach J, Hafner M, Gretz N. Murine models of polycystic kidney disease. Nephrol Dial Transplant. 1996;11 Suppl 6:38-45.

37. Alpers CE, Hudkins KL. Mouse models of diabetic nephropathy. Curr Opin Nephrol Hypertens. 2011;20(3):278-84.

38. Capecchi MR. Altering the genome by homologous recombination. Science. 1989;244(4910):1288-92.

39. Stricklett PK, Nelson RD, Kohan DE. The Cre/loxP system and gene targeting in the kidney. Am J Physiol. 1999;276(5 Pt 2):F651-7.

40. Silver LM. Mouse Genetics: concepts and applications. New York: Oxford University Press; 1995.

41. WareJoncas Z, Campbell JM, Martinez-Galvez G, Gendron WAC, Barry MA, Harris PC, et al. Precision gene editing technology and applications in nephrology. Nat Rev Nephrol. 2018;14(11):663-77.

42. Fernandez A, Josa S, Montoliu L. A history of genome editing in mammals. Mamm Genome. 2017;28(7-8):237-46.

43. Mianne J, Codner GF, Caulder A, Fell R, Hutchison M, King R, et al. Analysing the outcome of CRISPR-aided genome editing in embryos: Screening, genotyping and quality control. Methods. 2017;121-122:68-76.

44. Wilson JG, Roth CB, Warkany J. An analysis of the syndrome of malformations induced by maternal vitamin A deficiency. Effects of restoration of vitamin A at various times during gestation. Am J Anat. 1953;92(2):189-217.

45. El Kares R, Manolescu DC, Lakhal-Chaieb L, Montpetit A, Zhang Z, Bhat PV, et al. A human ALDH1A2 gene variant is associated with increased newborn kidney size and serum retinoic acid. Kidney Int. 2010;78(1):96-102.

46. Batourina E, Gim S, Bello N, Shy M, Clagett-Dame M, Srinivas S, et al. Vitamin A controls epithelial/mesenchymal interactions through Ret expression. Nat Genet. 2001;27(1):74-8.

47. Vlangos CN, Siuniak AN, Robinson D, Chinnaiyan AM, Lyons RH, Jr., Cavalcoli JD, et al. Next-generation sequencing identifies the Danforth's short tail mouse mutation as a retrotransposon insertion affecting Ptf1a expression. PLoS Genet. 2013;9(2):e1003205.

48. Maas R, Elfering S, Glaser T, Jepeal L. Deficient outgrowth of the ureteric bud underlies the renal agenesis phenotype in mice manifesting the limb deformity (ld) mutation. Devel Dynamics. 1994;199:214-28.

49. Torres M, Gomez-Pardo E, Dressler GR, Gruss P. Pax-2 controls multiple steps of urogenital development. Development. 1995;121(12):4057-65.

50. James RG, Kamei CN, Wang Q, Jiang R, Schultheiss TM. Odd-skipped related 1 is required for development of the metanephric kidney and regulates formation and differentiation of kidney precursor cells. Development. 2006;133(15):2995-3004.

51. Wang Q, Lan Y, Cho ES, Maltby KM, Jiang R. Odd-skipped related 1 (Odd 1) is an essential regulator of heart and urogenital development. Dev Biol. 2005;288(2):582-94. 
52. Lim KC, Lakshmanan G, Crawford SE, Gu Y, Grosveld F, Engel JD. Gata3 loss leads to embryonic lethality due to noradrenaline deficiency of the sympathetic nervous system. Nat Genet. 2000;25(2):209-12.

53. Shawlot W, Behringer RR. Requirement for Lim1 in head-organizer function. Nature. 1995;374(6521):425-30.

54. Tsang TE, Shawlot W, Kinder SJ, Kobayashi A, Kwan KM, Schughart K, et al. Lim1 activity is required for intermediate mesoderm differentiation in the mouse embryo. Dev Biol. 2000;223(1):77-90.

55. Kreidberg JA, Sariola H, Loring JM, Maeda M, Pelletier J, Housman D, et al. WT-1 is required for early kidney development. Cell. 1993;74:679-91.

56. Patterson LT, Pembaur M, Potter SS. Hoxa11 and Hoxd11 regulate branching morphogenesis of the ureteric bud in the developing kidney. Development. 2001;128(11):2153-61.

57. Patterson LT, Potter SS. Hox genes and kidney patterning. Curr Opin Nephrol Hypertens. 2003;12(1):19-23.

58. Xu PX, Adams J, Peters H, Brown MC, Heaney S, Maas R. Eya1-deficient mice lack ears and kidneys and show abnormal apoptosis of organ primordia. Nat Genet. 1999;23(1):113-7.

59. Xu PX, Zheng W, Huang L, Maire P, Laclef C, Silvius D. Six1 is required for the early organogenesis of mammalian kidney. Development. 2003;130(14):3085-94.

60. Nishinakamura R, Matsumoto Y, Nakao K, Nakamura K, Sato A, Copeland NG, et al. Murine homolog of SALL1 is essential for ureteric bud invasion in kidney development. Development. 2001;128(16):3105-15.

61. Moore MW, Klein RD, Farinas I, Sauer H, Armanini M, Phillips H, et al. Renal and neuronal abnormalities in mice lacking GDNF. Nature. 1996;382(6586):76-9.

62. Pichel JG, Shen L, Sheng HZ, Granholm AC, Drago J, Grinberg A, et al. Defects in enteric innervation and kidney development in mice lacking GDNF. Nature. 1996;382(6586):73-6.

63. Sanchez MP, Silos-Santiago I, Frisen J, He B, Lira SA, Barbacid M. Renal agenesis and the absence of enteric neurons in mice lacking GDNF. Nature. 1996;382(6586):70-3.

64. Schuchardt A, D'Agati V, Larsson-Blomberg L, Costantini F, Pachnis V. Defects in the kidney and enteric nervous system of mice lacking the tyrosine kinase receptor Ret. Nature. 1994;367(6461):380-3.

65. Schuchardt A, D'Agati V, Pachnis V, Costantini F. Renal agenesis and hypodysplasia in retk- mutant mice result from defects in ureteric bud development. Development. 1996;122(6):1919-29.

66. Cacalano G, Farinas I, Wang LC, Hagler K, Forgie A, Moore M, et al. GFRalpha1 is an essential receptor component for GDNF in the developing nervous system and kidney. Neuron. 1998;21(1):53-62.

67. Enomoto H, Araki T, Jackman A, Heuckeroth RO, Snider WD, Johnson EMJ, et al. GFR $\alpha 1-$ Deficient Mice Have Deficits in the Enteric Nervous System and Kidneys. Neuron. 1998;21(2):31724.

68. Costantini F. GDNF/Ret signaling and renal branching morphogenesis: From mesenchymal signals to epithelial cell behaviors. Organogenesis. 2010;6(4):252-62.

69. Lu BC, Cebrian C, Chi X, Kuure S, Kuo R, Bates CM, et al. Etv4 and Etv5 are required downstream of GDNF and Ret for kidney branching morphogenesis. Nat Genet. 2009;41(12):1295302.

70. Esquela AF, Lee SJ. Regulation of metanephric kidney development by growth/differentiation factor 11. Dev Biol. 2003;257(2):356-70.

71. Sanford LP, Ormsby I, Gittenberger-de Groot AC, Sariola H, Friedman R, Boivin GP, et al. TGFbeta2 knockout mice have multiple developmental defects that are non-overlapping with other TGFbeta knockout phenotypes. Development. 1997;124(13):2659-70. 
72. Shull MM, Ormsby I, Kier AB, Pawlowski S, Diebold RJ, Yin M, et al. Targeted disruption of the mouse transforming growth factor-beta 1 gene results in multifocal inflammatory disease. Nature. 1992;359(6397):693-9.

73. Kaartinen V, Voncken JW, Shuler C, Warburton D, Bu D, Heisterkamp N, et al. Abnormal lung development and cleft palate in mice lacking TGF-beta 3 indicates defects of epithelialmesenchymal interaction. Nat Genet. 1995;11(4):415-21.

74. Hsu DR, Economides AN, Wang X, Eimon PM, Harland RM. The Xenopus dorsalizing factor Gremlin identifies a novel family of secreted proteins that antagonize BMP activities. Mol Cell. 1998;1(5):673-83.

75. Michos O, Panman L, Vintersten K, Beier K, Zeller R, Zuniga A. Gremlin-mediated BMP antagonism induces the epithelial-mesenchymal feedback signaling controlling metanephric kidney and limb organogenesis. Development. 2004;131(14):3401-10.

76. Michos O, Goncalves A, Lopez-Rios J, Tiecke E, Naillat F, Beier K, et al. Reduction of BMP4 activity by gremlin 1 enables ureteric bud outgrowth and GDNF/WNT11 feedback signalling during kidney branching morphogenesis. Development. 2007;134(13):2397-405.

77. Poladia DP, Kish K, Kutay B, Hains D, Kegg H, Zhao H, et al. Role of fibroblast growth factor receptors 1 and 2 in the metanephric mesenchyme. Dev Biol. 2006;291(2):325-39.

78. Walker KA, Sims-Lucas S, Bates CM. Fibroblast growth factor receptor signaling in kidney and lower urinary tract development. Pediatr Nephrol. 2016;31(6):885-95.

79. Barak H, Huh SH, Chen S, Jeanpierre C, Martinovic J, Parisot M, et al. FGF9 and FGF20 maintain the stemness of nephron progenitors in mice and man. Dev Cell. 2012;22(6):1191-207.

80. Carroll TJ, Park JS, Hayashi S, Majumdar A, McMahon AP. Wnt9b plays a central role in the regulation of mesenchymal to epithelial transitions underlying organogenesis of the Mammalian urogenital system. Dev Cell. 2005;9(2):283-92.

81. Karner CM, Das A, Ma Z, Self M, Chen C, Lum L, et al. Canonical Wnt9b signaling balances progenitor cell expansion and differentiation during kidney development. Development. 2011;138(7):1247-57.

82. Kiefer SM, Robbins L, Rauchman M. Conditional expression of Wnt9b in Six2-positive cells disrupts stomach and kidney function. PLoS One. 2012;7(8):e43098.

83. Boivin FJ, Sarin S, Evans JC, Bridgewater D. The Good and Bad of beta-Catenin in Kidney Development and Renal Dysplasia. Front Cell Dev Biol. 2015;3:81.

84. Bridgewater D, Cox B, Cain J, Lau A, Athaide V, Gill PS, et al. Canonical WNT/beta-catenin signaling is required for ureteric branching. Dev Biol. 2008;317(1):83-94.

85. Lange A, Wickstrom SA, Jakobson M, Zent R, Sainio K, Fassler R. Integrin-linked kinase is an adaptor with essential functions during mouse development. Nature. 2009;461(7266):1002-6.

86. Mathew S, Chen X, Pozzi A, Zent R. Integrins in renal development. Pediatr Nephrol. 2012;27(6):891-900.

87. Vrontou S, Petrou P, Meyer BI, Galanopoulos VK, Imai K, Yanagi M, et al. Fras1 deficiency results in cryptophthalmos, renal agenesis and blebbed phenotype in mice. Nat Genet. 2003;34(2):209-14.

88. McGregor L, Makela V, Darling SM, Vrontou S, Chalepakis G, Roberts C, et al. Fraser syndrome and mouse blebbed phenotype caused by mutations in FRAS1/Fras1 encoding a putative extracellular matrix protein. Nat Genet. 2003;34(2):203-8.

89. Muller U, Wang D, Denda S, Meneses JJ, Pedersen RA, Reichardt LF. Integrin alpha8beta1 is critically important for epithelial-mesenchymal interactions during kidney morphogenesis. Cell. 1997;88(5):603-13.

90. Bader BL, Smyth N, Nedbal S, Miosge N, Baranowsky A, Mokkapati S, et al. Compound genetic ablation of nidogen 1 and 2 causes basement membrane defects and perinatal lethality in mice. Mol Cell Biol. 2005;25(15):6846-56. 
91. Nigam A, Knoers N, Renkema KY. Impact of next generation sequencing on our understanding of CAKUT. Semin Cell Dev Biol. 2018.

92. Saisawat P, Tasic V, Vega-Warner V, Kehinde EO, Gunther B, Airik R, et al. Identification of two novel CAKUT-causing genes by massively parallel exon resequencing of candidate genes in patients with unilateral renal agenesis. Kidney Int. 2012;81(2):196-200.

93. Meeus L, Gilbert B, Rydlewski C, Parma J, Roussie AL, Abramowicz M, et al. Characterization of a novel loss of function mutation of PAX8 in a familial case of congenital hypothyroidism with in-place, normal-sized thyroid. J Clin Endocrinol Metab. 2004;89(9):4285-91.

94. Hwang DY, Dworschak GC, Kohl S, Saisawat P, Vivante A, Hilger AC, et al. Mutations in 12 known dominant disease-causing genes clarify many congenital anomalies of the kidney and urinary tract. Kidney Int. 2014;85(6):1429-33.

95. Little SE, Hanks SP, King-Underwood L, Jones C, Rapley EA, Rahman N, et al. Frequency and heritability of WT1 mutations in nonsyndromic Wilms' tumor patients: a UK Children's Cancer Study Group Study. J Clin Oncol. 2004;22(20):4140-6.

96. Dode C, Levilliers J, Dupont JM, De Paepe A, Le Du N, Soussi-Yanicostas N, et al. Loss-offunction mutations in FGFR1 cause autosomal dominant Kallmann syndrome. Nat Genet. 2003;33(4):463-5.

97. Kohl S, Hwang DY, Dworschak GC, Hilger AC, Saisawat P, Vivante A, et al. Mild recessive mutations in six Fraser syndrome-related genes cause isolated congenital anomalies of the kidney and urinary tract. J Am Soc Nephrol. 2014;25(9):1917-22.

98. Skinner MA, Safford SD, Reeves JG, Jackson ME, Freemerman AJ. Renal aplasia in humans is associated with RET mutations. Am J Hum Genet. 2008;82(2):344-51.

99. Jadeja S, Smyth I, Pitera JE, Taylor MS, van Haelst M, Bentley E, et al. Identification of a new gene mutated in Fraser syndrome and mouse myelencephalic blebs. Nat Genet. 2005;37(5):5205 .

100. Humbert C, Silbermann F, Morar B, Parisot M, Zarhrate M, Masson C, et al. Integrin alpha 8 recessive mutations are responsible for bilateral renal agenesis in humans. Am J Hum Genet. 2014;94(2):288-94.

101. Albuisson J, Pecheux C, Carel JC, Lacombe D, Leheup B, Lapuzina P, et al. Kallmann syndrome: 14 novel mutations in KAL1 and FGFR1 (KAL2). Hum Mutat. 2005;25(1):98-9.

102. Heidet L, Moriniere V, Henry C, De Tomasi L, Reilly ML, Humbert C, et al. Targeted Exome Sequencing Identifies PBX1 as Involved in Monogenic Congenital Anomalies of the Kidney and Urinary Tract. J Am Soc Nephrol. 2017.

103. Uy N, Reidy K. Developmental Genetics and Congenital Anomalies of the Kidney and Urinary Tract. J Pediatr Genet. 2016;5(1):51-60.

104. Sanna-Cherchi S, Sampogna RV, Papeta N, Burgess KE, Nees SN, Perry BJ, et al. Mutations in DSTYK and dominant urinary tract malformations. N Engl J Med. 2013;369(7):621-9.

105. Weber S, Moriniere V, Knuppel T, Charbit M, Dusek J, Ghiggeri GM, et al. Prevalence of mutations in renal developmental genes in children with renal hypodysplasia: results of the ESCAPE study. J Am Soc Nephrol. 2006;17(10):2864-70.

106. Zhang Z, Iglesias D, Eliopoulos N, El Kares R, Chu L, Romagnani P, et al. A variant OSR1 allele which disturbs OSR1 mRNA expression in renal progenitor cells is associated with reduction of newborn kidney size and function. Hum Mol Genet. 2011;20(21):4167-74.

107. Favor J, Sandulache R, Neuhauser-Klaus A, Pretsch W, Chatterjee B, Senft E, et al. The mouse Pax2(1Neu) mutation is identical to a human PAX2 mutation in a family with renal-coloboma syndrome and results in developmental defects of the brain, ear, eye, and kidney. Proc Natl Acad Sci U S A. 1996;93(24):13870-5.

108. Zhang Z, Quinlan J, Hoy W, Hughson MD, Lemire M, Hudson T, et al. A common RET variant is associated with reduced newborn kidney size and function. J Am Soc Nephrol. 2008;19(10):2027-34. 
109. Chatterjee R, Ramos E, Hoffman M, VanWinkle J, Martin DR, Davis TK, et al. Traditional and targeted exome sequencing reveals common, rare and novel functional deleterious variants in RET-signaling complex in a cohort of living US patients with urinary tract malformations. Hum Genet. 2012;131(11):1725-38.

110. Barbacci E, Chalkiadaki A, Masdeu C, Haumaitre C, Lokmane L, Loirat C, et al. HNF1beta/TCF2 mutations impair transactivation potential through altered co-regulator recruitment. Hum Mol Genet. 2004;13(24):3139-49.

111. Weber S, Taylor JC, Winyard P, Baker KF, Sullivan-Brown J, Schild R, et al. SIX2 and BMP4 mutations associate with anomalous kidney development. J Am Soc Nephrol. 2008;19(5):891-903.

112. Jenkins D, Bitner-Glindzicz M, Malcolm S, Hu CC, Allison J, Winyard PJ, et al. De novo Uroplakin IIIa heterozygous mutations cause human renal adysplasia leading to severe kidney failure. J Am Soc Nephrol. 2005;16(7):2141-9.

113. Nixon TRW, Richards A, Towns LK, Fuller G, Abbs S, Alexander P, et al. Bone morphogenetic protein 4 (BMP4) loss-of-function variant associated with autosomal dominant Stickler syndrome and renal dysplasia. Eur J Hum Genet. 2018.

114. Brzoska HL, d'Esposito AM, Kolatsi-Joannou M, Patel V, Igarashi P, Lei Y, et al. Planar cell polarity genes Celsr1 and Vangl2 are necessary for kidney growth, differentiation, and rostrocaudal patterning. Kidney Int. 2016;90(6):1274-84.

115. Schedl A. Renal abnormalities and their developmental origin. Nat Rev Genet. 2007;8(10):791-802.

116. Thomas R, Sanna-Cherchi S, Warady BA, Furth SL, Kaskel FJ, Gharavi AG. HNF1B and PAX2 mutations are a common cause of renal hypodysplasia in the CKiD cohort. Pediatr Nephrol. 2011;26(6):897-903.

117. Paces-Fessy M, Fabre M, Lesaulnier C, Cereghini S. Hnf1b and Pax2 cooperate to control different pathways in kidney and ureter morphogenesis. Hum Mol Genet. 2012;21(14):3143-55.

118. Barbacci E, Reber M, Ott MO, Breillat C, Huetz F, Cereghini S. Variant hepatocyte nuclear factor 1 is required for visceral endoderm specification. Development. 1999;126(21):4795-805.

119. Lokmane L, Heliot C, Garcia-Villalba P, Fabre M, Cereghini S. vHNF1 functions in distinct regulatory circuits to control ureteric bud branching and early nephrogenesis. Development. 2010;137(2):347-57.

120. Heliot C, Desgrange A, Buisson I, Prunskaite-Hyyrylainen R, Shan J, Vainio S, et al. HNF1B controls proximal-intermediate nephron segment identity in vertebrates by regulating Notch signalling components and Irx1/2. Development. 2013;140(4):873-85.

121. Desgrange A, Heliot C, Skovorodkin I, Akram SU, Heikkila J, Ronkainen VP, et al. HNF1B controls epithelial organization and cell polarity during ureteric bud branching and collecting duct morphogenesis. Development. 2017;144(24):4704-19.

122. Reginensi A, Clarkson M, Neirijnck Y, Lu B, Ohyama T, Groves AK, et al. SOX9 controls epithelial branching by activating RET effector genes during kidney development. Hum Mol Genet. 2011.

123. Liu J, Krautzberger AM, Sui SH, Hofmann OM, Chen Y, Baetscher M, et al. Cell-specific translational profiling in acute kidney injury. J Clin Invest. 2014;124(3):1242-54.

124. Kumar S, Liu J, Pang P, Krautzberger AM, Reginensi A, Akiyama H, et al. Sox9 Activation Highlights a Cellular Pathway of Renal Repair in the Acutely Injured Mammalian Kidney. Cell reports. 2015;12(8):1325-38.

125. Nagata M, Nakauchi H, Nakayama K, Nakayama K, Loh D, Watanabe T. Apoptosis during an early stage of nephrogenesis induces renal hypoplasia in bcl-2-deficient mice. Am J Pathol. 1996;148(5):1601-11.

126. Self M, Lagutin OV, Bowling B, Hendrix J, Cai Y, Dressler GR, et al. Six2 is required for suppression of nephrogenesis and progenitor renewal in the developing kidney. EMBO J. 2006;25(21):5214-28. 
127. Rosselot C, Spraggon L, Chia I, Batourina E, Riccio P, Lu B, et al. Non-cell-autonomous retinoid signaling is crucial for renal development. Development. 2010;137(2):283-92.

128. Nishinakamura R, Sakaguchi M. BMP signaling and its modifiers in kidney development. Pediatr Nephrol. 2014;29(4):681-6.

129. Oxburgh L, Brown AC, Muthukrishnan SD, Fetting JL. Bone morphogenetic protein signaling in nephron progenitor cells. Pediatr Nephrol. 2014;29(4):531-6.

130. Wang Y, Zhou CJ, Liu Y. Wnt Signaling in Kidney Development and Disease. Prog Mol Biol Transl Sci. 2018;153:181-207.

131. Halt K, Vainio S. Coordination of kidney organogenesis by Wnt signaling. Pediatr Nephrol. 2014;29(4):737-44.

132. Brown AC, Muthukrishnan SD, Guay JA, Adams DC, Schafer DA, Fetting JL, et al. Role for compartmentalization in nephron progenitor differentiation. Proc Natl Acad Sci U S A. 2013;110(12):4640-5.

133. Dudley AT, Lyons KM, Robertson EJ. A requirement for bone morphogenetic protein-7 during development of the mammalian kidney and eye. Genes Dev. 1995;9:2795-807.

134. Luo G, Hofmann C, Bronckers AL, Sohocki M, Bradley A, Karsenty G. BMP-7 is an inducer of nephrogenesis, and is also required for eye development and skeletal patterning. Genes Dev. 1995;9(22):2808-20.

135. Tomita M, Asada M, Asada N, Nakamura J, Oguchi A, Higashi AY, et al. Bmp7 maintains undifferentiated kidney progenitor population and determines nephron numbers at birth. PLoS One. 2013;8(8):e73554.

136. Oxburgh L, Dudley AT, Godin RE, Koonce CH, Islam A, Anderson DC, et al. BMP4 substitutes for loss of BMP7 during kidney development. Dev Biol. 2005;286(2):637-46.

137. Goncalves A, Zeller R. Genetic analysis reveals an unexpected role of BMP7 in initiation of ureteric bud outgrowth in mouse embryos. PLoS One. 2011;6(4):e19370.

138. Hartwig S, Bridgewater D, Di Giovanni V, Cain J, Mishina Y, Rosenblum ND. BMP receptor ALK3 controls collecting system development. J Am Soc Nephrol. 2008;19(1):117-24.

139. Sakaguchi M, Sharmin S, Taguchi A, Ohmori T, Fujimura S, Abe T, et al. The phosphatase Dullard negatively regulates BMP signalling and is essential for nephron maintenance after birth. Nat Commun. 2013;4:1398.

140. Ikeya M, Kawada M, Kiyonari H, Sasai N, Nakao K, Furuta Y, et al. Essential pro-Bmp roles of crossveinless 2 in mouse organogenesis. Development. 2006;133(22):4463-73.

141. Ikeya M, Fukushima K, Kawada M, Onishi S, Furuta Y, Yonemura S, et al. Cv2, functioning as a pro-BMP factor via twisted gastrulation, is required for early development of nephron precursors. Dev Biol. 2010;337(2):405-14.

142. Muthukrishnan SD, Yang X, Friesel R, Oxburgh L. Concurrent BMP7 and FGF9 signalling governs AP-1 function to promote self-renewal of nephron progenitor cells. Nat Commun. 2015;6:10027.

143. Saxen L, Lehtonen E. Transfilter induction of kidney tubules as a function of the extent and duration of intercellular contacts. J Embryol Exp Morphol. 1978;47:97-109.

144. Itaranta P, Lin Y, Perasaari J, Roel G, Destree O, Vainio S. Wnt-6 is expressed in the ureter bud and induces kidney tubule development in vitro. Genesis. 2002;32(4):259-68.

145. Stark K, Vainio S, Vassileva G, McMahon AP. Epithelial transformation of metanephric mesenchyme in the developing kidney regulated by Wnt-4. Nature. 1994;372(6507):679-83.

146. Park JS, Valerius MT, McMahon AP. Wnt/beta-catenin signaling regulates nephron induction during mouse kidney development. Development. 2007;134(13):2533-9.

147. Kuure S, Popsueva A, Jakobson M, Sainio K, Sariola H. Glycogen synthase kinase-3 inactivation and stabilization of beta-catenin induce nephron differentiation in isolated mouse and rat kidney mesenchymes. J Am Soc Nephrol. 2007;18(4):1130-9. 
148. Marose TD, Merkel CE, McMahon AP, Carroll TJ. Beta-catenin is necessary to keep cells of ureteric bud/Wolffian duct epithelium in a precursor state. Dev Biol. 2008;314(1):112-26.

149. Bridgewater D, Di Giovanni V, Cain JE, Cox B, Jakobson M, Sainio K, et al. beta-catenin causes renal dysplasia via upregulation of Tgfbeta2 and Dkk1. J Am Soc Nephrol. 2011;22(4):71831.

150. Song R, El-Dahr SS, Yosypiv IV. Receptor tyrosine kinases in kidney development. Journal of signal transduction. 2011;2011:869281.

151. Jain S, Encinas M, Johnson EM, Jr., Milbrandt J. Critical and distinct roles for key RET tyrosine docking sites in renal development. Genes Dev. 2006;20(3):321-33.

152. Jain S, Knoten A, Hoshi M, Wang H, Vohra B, Heuckeroth RO, et al. Organotypic specificity of key RET adaptor-docking sites in the pathogenesis of neurocristopathies and renal malformations in mice. J Clin Invest. 2010;120(3):778-90.

153. de Graaff E, Srinivas S, Kilkenny C, D'Agati V, Mankoo BS, Costantini F, et al. Differential activities of the RET tyrosine kinase receptor isoforms during mammalian embryogenesis. Genes Dev. 2001;15(18):2433-44.

154. Jijiwa M, Fukuda T, Kawai K, Nakamura A, Kurokawa K, Murakumo Y, et al. A targeting mutation of tyrosine 1062 in Ret causes a marked decrease of enteric neurons and renal hypoplasia. Mol Cell Biol. 2004;24(18):8026-36.

155. Fisher CE, Michael L, Barnett MW, Davies JA. Erk MAP kinase regulates branching morphogenesis in the developing mouse kidney. Development. 2001;128(21):4329-38.

156. Tang MJ, Cai Y, Tsai SJ, Wang YK, Dressler GR. Ureteric bud outgrowth in response to RET activation is mediated by phosphatidylinositol 3-kinase. Dev Biol. 2002;243(1):128-36.

157. Willecke R, Heuberger J, Grossmann K, Michos O, Schmidt-Ott K, Walentin K, et al. The tyrosine phosphatase Shp2 acts downstream of GDNF/Ret in branching morphogenesis of the developing mouse kidney. Dev Biol. 2011;360(2):310-7.

158. Ihermann-Hella A, Lume M, Miinalainen IJ, Pirttiniemi A, Gui Y, Peranen J, et al. Mitogenactivated protein kinase (MAPK) pathway regulates branching by remodeling epithelial cell adhesion. PLoS Genet. 2014;10(3):e1004193.

159. Kim D, Dressler GR. PTEN modulates GDNF/RET mediated chemotaxis and branching morphogenesis in the developing kidney. Dev Biol. 2007;307(2):290-9.

160. Enderle L, McNeill H. Hippo gains weight: added insights and complexity to pathway control. Sci Signal. 2013;6(296):re7.

161. Reginensi A, Enderle L, Gregorieff A, Johnson RL, Wrana JL, McNeill H. A critical role for NF2 and the Hippo pathway in branching morphogenesis. Nat Commun. 2016;7:12309.

162. McNeill H, Reginensi A. Lats1/2 Regulate Yap/Taz to Control Nephron Progenitor Epithelialization and Inhibit Myofibroblast Formation. J Am Soc Nephrol. 2017;28(3):852-61.

163. Reginensi A, Scott RP, Gregorieff A, Bagherie-Lachidan M, Chung C, Lim DS, et al. Yapand Cdc42-dependent nephrogenesis and morphogenesis during mouse kidney development. PLoS Genet. 2013;9(3):e1003380.

164. Hossain Z, Ali SM, Ko HL, Xu J, Ng CP, Guo K, et al. Glomerulocystic kidney disease in mice with a targeted inactivation of Wwtr1. Proc Natl Acad Sci U S A. 2007;104(5):1631-6.

165. Makita R, Uchijima Y, Nishiyama K, Amano T, Chen Q, Takeuchi T, et al. Multiple renal cysts, urinary concentration defects, and pulmonary emphysematous changes in mice lacking TAZ. Am J Physiol Renal Physiol. 2008;294(3):F542-53.

166. Yates LL, Papakrivopoulou J, Long DA, Goggolidou P, Connolly JO, Woolf AS, et al. The planar cell polarity gene Vangl2 is required for mammalian kidney-branching morphogenesis and glomerular maturation. Hum Mol Genet. 2010;19(23):4663-76.

167. Kuure S, Cebrian C, Machingo Q, Lu BC, Chi X, Hyink D, et al. Actin depolymerizing factors cofilin1 and destrin are required for ureteric bud branching morphogenesis. PLoS Genet. 2010;6(10):e1001176. 
168. Marciano DK, Brakeman PR, Lee CZ, Spivak N, Eastburn DJ, Bryant DM, et al. p120 catenin is required for normal renal tubulogenesis and glomerulogenesis. Development. 2011;138(10):2099109.

169. Mackie GG, Stephens FD. Duplex kidneys: a correlation of renal dysplasia with position of the ureteral orifice. J Urol. 1975;114(2):274-80.

170. Miyazaki Y, Oshima K, Fogo A, Hogan BL, Ichikawa I. Bone morphogenetic protein 4 regulates the budding site and elongation of the mouse ureter. J Clin Invest. 2000;105(7):863-73.

171. Batourina E, Choi C, Paragas N, Bello N, Hensle T, Costantini FD, et al. Distal ureter morphogenesis depends on epithelial cell remodeling mediated by vitamin A and Ret. Nat Genet. 2002;32(1):109-15.

172. Batourina E, Tsai S, Lambert S, Sprenkle P, Viana R, Dutta S, et al. Apoptosis induced by vitamin A signaling is crucial for connecting the ureters to the bladder. Nat Genet. 2005;37(10):10829.

173. Chia I, Grote D, Marcotte M, Batourina E, Mendelsohn C, Bouchard M. Nephric duct insertion is a crucial step in urinary tract maturation that is regulated by a Gata3-Raldh2-Ret molecular network in mice. Development. 2011;138(10):2089-97.

174. Kumar A, Kopra J, Varendi K, Porokuokka LL, Panhelainen A, Kuure S, et al. GDNF Overexpression from the Native Locus Reveals its Role in the Nigrostriatal Dopaminergic System Function. PLoS Genet. 2015;11(12):e1005710.

175. Li H, Jakobson, M., Ola, R., Gui, Y., Kumar, A., Sipilä, P., Sariola, H., Kuure, S., and Andressoo, J.O. Development of the urogenital system is regulated via the 3'UTR of GDNF. Scientific reports. 2019;Accepted.

176. Mendelsohn C, Lohnes D, Decimo D, Lufkin T, LeMeur M, Chambon P, et al. Function of the retinoic acid receptors (RARs) during development (II). Multiple abnormalities at various stages of organogenesis in RAR double mutants. Development. 1994;120(10):2749-71.

177. Airik R, Trowe MO, Foik A, Farin HF, Petry M, Schuster-Gossler K, et al. Hydroureternephrosis due to loss of Sox9-regulated smooth muscle cell differentiation of the ureteric mesenchyme. Hum Mol Genet. 2010;19(24):4918-29.

178. Neirijnck Y, Reginensi A, Renkema KY, Massa F, Kozlov VM, Dhib H, et al. Sox11 gene disruption causes congenital anomalies of the kidney and urinary tract (CAKUT). Kidney Int. 2018;93(5):1142-53.

179. Airik R, Bussen M, Singh MK, Petry M, Kispert A. Tbx18 regulates the development of the ureteral mesenchyme. J Clin Invest. 2006;116(3):663-74.

180. Vivante A, Kleppa MJ, Schulz J, Kohl S, Sharma A, Chen J, et al. Mutations in TBX18 Cause Dominant Urinary Tract Malformations via Transcriptional Dysregulation of Ureter Development. Am J Hum Genet. 2015;97(2):291-301.

181. Jeanpierre C, Mace G, Parisot M, Moriniere V, Pawtowsky A, Benabou M, et al. RET and GDNF mutations are rare in fetuses with renal agenesis or other severe kidney development defects. J Med Genet. 2011;48(7):497-504.

182. Fernbach SK, Feinstein KA, Spencer K, Lindstrom CA. Ureteral duplication and its complications. Radiographics. 1997;17(1):109-27.

183. Shakya R, Jho EH, Kotka P, Wu Z, Kholodilov N, Burke R, et al. The role of GDNF in patterning the excretory system. Dev Biol. 2005;283:70-84.

184. Sainio K, Suvanto P, Davies J, Wartiovaara J, Wartiovaara K, Saarma M, et al. Glial-cellline-derived neurotrophic factor is required for bud initiation from ureteric epithelium. Development. 1997;124(20):4077-87.

185. Grieshammer U, Le M, Plump AS, Wang F, Tessier-Lavigne M, Martin GR. SLIT2-mediated ROBO2 signaling restricts kidney induction to a single site. Dev Cell. 2004;6(5):709-17. 
186. Wainwright EN, Wilhelm D, Combes AN, Little MH, Koopman P. ROBO2 restricts the nephrogenic field and regulates Wolffian duct-nephrogenic cord separation. Dev Biol. 2015;404(2):88-102.

187. Kume T, Deng K, Hogan BL. Murine forkhead/winged helix genes Foxc1 (Mf1) and Foxc2 (Mfh1) are required for the early organogenesis of the kidney and urinary tract. Development. 2000;127(7):1387-95.

188. Chi L, Zhang S, Lin Y, Prunskaite-Hyyrylainen R, Vuolteenaho R, Itaranta P, et al. Sprouty proteins regulate ureteric branching by coordinating reciprocal epithelial Wnt11, mesenchymal Gdnf and stromal Fgf7 signalling during kidney development. Development. 2004;131(14):3345-56.

189. Basson MA, Akbulut S, Watson-Johnson J, Simon R, Carroll TJ, Shakya R, et al. Sprouty1 is a critical regulator of GDNF/RET-mediated kidney induction. Dev Cell. 2005;8(2):229-39.

190. Rozen EJ, Schmidt H, Dolcet X, Basson MA, Jain S, Encinas M. Loss of Sprouty1 rescues renal agenesis caused by Ret mutation. J Am Soc Nephrol. 2009;20(2):255-9.

191. Michos O, Cebrian C, Hyink D, Grieshammer U, Williams L, D'Agati V, et al. Kidney development in the absence of Gdnf and Spry1 requires Fgf10. PLoS Genet. 2010;6(1):e1000809.

192. Maeshima A, Sakurai H, Choi Y, Kitamura S, Vaughn DA, Tee JB, et al. Glial cell-derived neurotrophic factor independent ureteric bud outgrowth from the Wolffian duct. J Am Soc Nephrol. 2007;18(12):3147-55.

193. Peng Y, Clark C, Luong R, Tu WH, Lee J, Johnson DT, et al. The leucine zipper putative tumor suppressor 2 protein LZTS2 regulates kidney development. J Biol Chem. 2011;286(46):4033142.

194. Kaku Y, Ohmori T, Kudo K, Fujimura S, Suzuki K, Evans SM, et al. Islet1 deletion causes kidney agenesis and hydroureter resembling CAKUT. J Am Soc Nephrol. 2013;24(8):1242-9.

195. Tabatabaeifar M, Schlingmann KP, Litwin M, Emre S, Bakkaloglu A, Mehls O, et al. Functional analysis of BMP4 mutations identified in pediatric CAKUT patients. Pediatr Nephrol. 2009;24(12):2361-8.

196. Gimelli S, Caridi G, Beri S, McCracken K, Bocciardi R, Zordan P, et al. Mutations in SOX17 are associated with congenital anomalies of the kidney and the urinary tract. Hum Mutat. 2010;31(12):1352-9.

197. Weber S, Landwehr C, Renkert M, Hoischen A, Wuhl E, Denecke J, et al. Mapping candidate regions and genes for congenital anomalies of the kidneys and urinary tract (CAKUT) by array-based comparative genomic hybridization. Nephrol Dial Transplant. 2011;26(1):136-43.

198. Bertoli-Avella AM, Conte ML, Punzo F, de Graaf BM, Lama G, La Manna A, et al. ROBO2 gene variants are associated with familial vesicoureteral reflux. J Am Soc Nephrol. 2008;19(4):82531.

199. Lu W, van Eerde AM, Fan X, Quintero-Rivera F, Kulkarni S, Ferguson H, et al. Disruption of ROBO2 is associated with urinary tract anomalies and confers risk of vesicoureteral reflux. Am J Hum Genet. 2007;80(4):616-32.

200. van Eerde AM, Duran K, van Riel E, de Kovel CG, Koeleman BP, Knoers NV, et al. Genes in the ureteric budding pathway: association study on vesico-ureteral reflux patients. PLoS One. 2012;7(4):e31327.

201. Siebert JR. Perinatal, fetal and embryonic autopsy. In: Siebert EG-BRKLLOJ, editor. Potter's Pathology of the Fetus, Infant and Child. 2nd: Elsevier; 2007. p. 695-736.

202. Tripathi P, Guo Q, Wang Y, Coussens M, Liapis H, Jain S, et al. Midline signaling regulates kidney positioning but not nephrogenesis through Shh. Dev Biol. 2010;340(2):518-27.

203. Abu-Abed S, Dolle P, Metzger D, Beckett B, Chambon P, Petkovich M. The retinoic acidmetabolizing enzyme, CYP26A1, is essential for normal hindbrain patterning, vertebral identity, and development of posterior structures. Genes Dev. 2001;15(2):226-40. 
204. Sakai Y, Meno C, Fujii H, Nishino J, Shiratori H, Saijoh Y, et al. The retinoic acid-inactivating enzyme CYP26 is essential for establishing an uneven distribution of retinoic acid along the anterioposterior axis within the mouse embryo. Genes Dev. 2001;15(2):213-25.

205. Hatini V, Huh SO, Herzlinger D, Soares VC, Lai E. Essential role of stromal mesenchyme in kidney morphogenesis revealed by targeted disruption of Winged Helix transcription factor BF-2. Genes Dev. 1996;10(12):1467-78.

206. Levinson RS, Batourina E, Choi C, Vorontchikhina M, Kitajewski J, Mendelsohn CL. Foxd1dependent signals control cellularity in the renal capsule, a structure required for normal renal development. Development. 2005;132(3):529-39.

207. Nicolaou N, Pulit SL, Nijman IJ, Monroe GR, Feitz WF, Schreuder MF, et al. Prioritization and burden analysis of rare variants in 208 candidate genes suggest they do not play a major role in CAKUT. Kidney Int. 2016;89(2):476-86.

208. Jing J, Pattaro C, Hoppmann A, Okada Y, Consortium CK, Fox CS, et al. Combination of mouse models and genomewide association studies highlights novel genes associated with human kidney function. Kidney Int. 2016;90(4):764-73.

209. Fetterman GH, Ravitch MM, Sherman FE. Cystic changes in fetal kidneys following ureteral ligation: studies by microdissection. Kidney Int. 1974;5(2):111-21.

210. Bergmann C, Guay-Woodford LM, Harris PC, Horie S, Peters DJM, Torres VE. Polycystic kidney disease. Nat Rev Dis Primers. 2018;4(1):50.

211. Kraus MR, Clauin S, Pfister Y, Di Maio M, Ulinski T, Constam D, et al. Two mutations in human BICC1 resulting in Wnt pathway hyperactivity associated with cystic renal dysplasia. Hum Mutat. 2012;33(1):86-90.

212. Groenen PM, Vanderlinden G, Devriendt K, Fryns JP, Van de Ven WJ. Rearrangement of the human CDC5L gene by a $\mathrm{t}(6 ; 19)(\mathrm{p} 21 ; \mathrm{q} 13.1)$ in a patient with multicystic renal dysplasia. Genomics. 1998;49(2):218-29.

213. Schild R, Knuppel T, Konrad M, Bergmann C, Trautmann A, Kemper MJ, et al. Double homozygous missense mutations in DACH1 and BMP4 in a patient with bilateral cystic renal dysplasia. Nephrol Dial Transplant. 2013;28(1):227-32.

214. Verdeguer F, Le Corre S, Fischer E, Callens C, Garbay S, Doyen A, et al. A mitotic transcriptional switch in polycystic kidney disease. Nat Med. 2010;16(1):106-10.

215. Heidet L, Decramer S, Pawtowski A, Moriniere V, Bandin F, Knebelmann B, et al. Spectrum of HNF1B mutations in a large cohort of patients who harbor renal diseases. Clin J Am Soc Nephrol. 2010;5(6):1079-90.

216. Groenen PM, Garcia E, Debeer P, Devriendt K, Fryns JP, Van de Ven WJ. Structure, sequence, and chromosome 19 localization of human USF2 and its rearrangement in a patient with multicystic renal dysplasia. Genomics. 1996;38(2):141-8.

217. Cordido A, Besada-Cerecedo L, Garcia-Gonzalez MA. The Genetic and Cellular Basis of Autosomal Dominant Polycystic Kidney Disease-A Primer for Clinicians. Front Pediatr. 2017;5:279. 218. Nagao S, Kugita M, Yoshihara D, Yamaguchi T. Animal models for human polycystic kidney disease. Exp Anim. 2012;61(5):477-88.

219. Porath B, Gainullin VG, Cornec-Le Gall E, Dillinger EK, Heyer CM, Hopp K, et al. Mutations in GANAB, Encoding the Glucosidase IIalpha Subunit, Cause Autosomal-Dominant Polycystic Kidney and Liver Disease. Am J Hum Genet. 2016;98(6):1193-207.

220. Bergmann C. Genetics of Autosomal Recessive Polycystic Kidney Disease and Its Differential Diagnoses. Front Pediatr. 2017;5:221.

221. Lu H, Galeano MCR, Ott E, Kaeslin G, Kausalya PJ, Kramer C, et al. Mutations in DZIP1L, which encodes a ciliary-transition-zone protein, cause autosomal recessive polycystic kidney disease. Nat Genet. 2017;49(7):1025-34.

222. Horikawa Y, Iwasaki N, Hara M, Furuta H, Hinokio Y, Cockburn BN, et al. Mutation in hepatocyte nuclear factor-1 beta gene (TCF2) associated with MODY. Nat Genet. 1997;17(4):384-5. 
223. Lantinga-van Leeuwen IS, Leonhard WN, van der Wal A, Breuning MH, de Heer E, Peters DJ. Kidney-specific inactivation of the Pkd1 gene induces rapid cyst formation in developing kidneys and a slow onset of disease in adult mice. Hum Mol Genet. 2007;16(24):3188-96.

224. Mochizuki T, Wu G, Hayashi T, Xenophontos SL, Veldhuisen B, Saris JJ, et al. PKD2, a gene for polycystic kidney disease that encodes an integral membrane protein. Science. 1996;272(5266):1339-42.

225. Wu G, D'Agati V, Cai Y, Markowitz G, Park JH, Reynolds DM, et al. Somatic inactivation of Pkd2 results in polycystic kidney disease. Cell. 1998;93(2):177-88.

226. Ward CJ, Hogan MC, Rossetti S, Walker D, Sneddon T, Wang X, et al. The gene mutated in autosomal recessive polycystic kidney disease encodes a large, receptor-like protein. Nat Genet. 2002;30(3):259-69.

227. Lin F, Hiesberger T, Cordes K, Sinclair AM, Goldstein LS, Somlo S, et al. Kidney-specific inactivation of the KIF3A subunit of kinesin-II inhibits renal ciliogenesis and produces polycystic kidney disease. Proc Natl Acad Sci U S A. 2003;100(9):5286-91.

228. Fedeles SV, Tian X, Gallagher AR, Mitobe M, Nishio S, Lee SH, et al. A genetic interaction network of five genes for human polycystic kidney and liver diseases defines polycystin-1 as the central determinant of cyst formation. Nat Genet. 2011;43(7):639-47.

229. Saburi S, Hester I, Fischer E, Pontoglio M, Eremina V, Gessler M, et al. Loss of Fat4 disrupts PCP signaling and oriented cell division and leads to cystic kidney disease. Nat Genet. 2008;40(8):1010-5.

230. Mao Y, Mulvaney J, Zakaria S, Yu T, Morgan KM, Allen S, et al. Characterization of a Dchs1 mutant mouse reveals requirements for Dchs1-Fat4 signaling during mammalian development. Development. 2011;138(5):947-57.

231. Nechiporuk T, Fernandez TE, Vasioukhin V. Failure of epithelial tube maintenance causes hydrocephalus and renal cysts in Dlg5-/- mice. Dev Cell. 2007;13(3):338-50.

232. Cano-Gauci DF, Song HH, Yang H, McKerlie C, Choo B, Shi W, et al. Glypican-3-deficient mice exhibit developmental overgrowth and some of the abnormalities typical of Simpson-GolabiBehmel syndrome. J Cell Biol. 1999;146(1):255-64.

233. Holmberg C, Jalanko H. Congenital nephrotic syndrome and recurrence of proteinuria after renal transplantation. Pediatr Nephrol. 2014;29(12):2309-17.

234. Spahiu L, Merovci B, Jashari H, Kepuska AB, Rugova BE. Congenital Nephrotic Syndrome - Finish Type. Med Arch. 2016;70(3):232-4.

235. Kestila M, Lenkkeri U, Mannikko M, Lamerdin J, McCready P, Putaala H, et al. Positionally cloned gene for a novel glomerular protein--nephrin--is mutated in congenital nephrotic syndrome. Mol Cell. 1998;1(4):575-82.

236. Lenkkeri U, Mannikko M, McCready P, Lamerdin J, Gribouval O, Niaudet PM, et al. Structure of the gene for congenital nephrotic syndrome of the finnish type (NPHS1) and characterization of mutations. Am J Hum Genet. 1999;64(1):51-61.

237. Hinkes BG, Mucha B, Vlangos CN, Gbadegesin R, Liu J, Hasselbacher K, et al. Nephrotic syndrome in the first year of life: two thirds of cases are caused by mutations in 4 genes (NPHS1, NPHS2, WT1, and LAMB2). Pediatrics. 2007;119(4):e907-19.

238. Cil O, Besbas N, Duzova A, Topaloglu R, Peco-Antic A, Korkmaz E, et al. Genetic abnormalities and prognosis in patients with congenital and infantile nephrotic syndrome. Pediatr Nephrol. 2015;30(8):1279-87.

239. Boute N, Gribouval O, Roselli S, Benessy F, Lee H, Fuchshuber A, et al. NPHS2, encoding the glomerular protein podocin, is mutated in autosomal recessive steroid-resistant nephrotic syndrome. Nat Genet. 2000;24(4):349-54.

240. Gbadegesin R, Hinkes BG, Hoskins BE, Vlangos CN, Heeringa SF, Liu J, et al. Mutations in PLCE1 are a major cause of isolated diffuse mesangial sclerosis (IDMS). Nephrol Dial Transplant. 2008;23(4):1291-7. 
241. Jeanpierre C, Denamur E, Henry I, Cabanis MO, Luce S, Cecille A, et al. Identification of constitutional WT1 mutations, in patients with isolated diffuse mesangial sclerosis, and analysis of genotype/phenotype correlations by use of a computerized mutation database. Am J Hum Genet. 1998;62(4):824-33.

242. Gee HY, Sadowski CE, Aggarwal PK, Porath JD, Yakulov TA, Schueler M, et al. FAT1 mutations cause a glomerulotubular nephropathy. Nat Commun. 2016;7:10822.

243. Zenker M, Aigner T, Wendler O, Tralau T, Muntefering H, Fenski R, et al. Human laminin beta2 deficiency causes congenital nephrosis with mesangial sclerosis and distinct eye abnormalities. Hum Mol Genet. 2004;13(21):2625-32.

244. Kashtan CE, Ding J, Garosi G, Heidet L, Massella L, Nakanishi K, et al. Alport syndrome: a unified classification of genetic disorders of collagen IV alpha345: a position paper of the Alport Syndrome Classification Working Group. Kidney Int. 2018;93(5):1045-51.

245. Putaala H, Soininen R, Kilpelainen P, Wartiovaara J, Tryggvason K. The murine nephrin gene is specifically expressed in kidney, brain and pancreas: inactivation of the gene leads to massive proteinuria and neonatal death. Hum Mol Genet. 2001;10(1):1-8.

246. Ratelade J, Lavin TA, Muda AO, Morisset L, Mollet G, Boyer O, et al. Maternal environment interacts with modifier genes to influence progression of nephrotic syndrome. J Am Soc Nephrol. 2008;19(8):1491-9.

247. Noakes PG, Miner JH, Gautam M, Cunningham JM, Sanes JR, Merlie JP. The renal glomerulus of mice lacking s-laminin/laminin beta 2: nephrosis despite molecular compensation by laminin beta 1. Nat Genet. 1995;10(4):400-6.

248. Jarad G, Cunningham J, Shaw AS, Miner JH. Proteinuria precedes podocyte abnormalities inLamb2-/- mice, implicating the glomerular basement membrane as an albumin barrier. J Clin Invest. 2006;116(8):2272-9.

249. Kang JS, Wang XP, Miner JH, Morello R, Sado Y, Abrahamson DR, et al. Loss of alpha3/alpha4(IV) collagen from the glomerular basement membrane induces a strain-dependent isoform switch to alpha5alpha6(IV) collagen associated with longer renal survival in Co14a3-/- Alport mice. J Am Soc Nephrol. 2006;17(7):1962-9.

250. Kim JM, Wu H, Green G, Winkler CA, Kopp JB, Miner JH, et al. CD2-associated protein haploinsufficiency is linked to glomerular disease susceptibility. Science. 2003;300(5623):1298-300.

251. Machuca E, Benoit G, Antignac C. Genetics of nephrotic syndrome: connecting molecular genetics to podocyte physiology. Hum Mol Genet. 2009;18(R2):R185-94.

252. Caban C, Khan N, Hasbani DM, Crino PB. Genetics of tuberous sclerosis complex: implications for clinical practice. Appl Clin Genet. 2017;10:1-8.

253. Ogawa O, Eccles MR, Szeto J, McNoe LA, Yun K, Maw MA, et al. Relaxation of insulinlike growth factor II gene imprinting implicated in Wilms' tumour. Nature. 1993;362(6422):749-51. 254. Hohenstein P, Pritchard-Jones K, Charlton J. The yin and yang of kidney development and Wilms' tumors. Genes Dev. 2015;29(5):467-82.

255. Park S, Bernard A, Bove KE, Sens DA, Hazen-Martin DJ, Garvin AJ, et al. Inactivation of WT1 in nephrogenic rests, genetic precursors to Wilms' tumour. Nat Genet. 1993;5(4):363-7.

256. Koesters R, Ridder R, Kopp-Schneider A, Betts D, Adams V, Niggli F, et al. Mutational activation of the beta-catenin proto-oncogene is a common event in the development of Wilms' tumors. Cancer Res. 1999;59(16):3880-2.

257. Maiti S, Alam R, Amos CI, Huff V. Frequent association of beta-catenin and WT1 mutations in Wilms tumors. Cancer Res. 2000;60(22):6288-92.

258. Rivera MN, Kim WJ, Wells J, Driscoll DR, Brannigan BW, Han M, et al. An X chromosome gene, WTX, is commonly inactivated in Wilms tumor. Science. 2007;315(5812):642-5.

259. Major MB, Camp ND, Berndt JD, Yi X, Goldenberg SJ, Hubbert C, et al. Wilms tumor suppressor WTX negatively regulates WNT/beta-catenin signaling. Science. 2007;316(5827):10436. 
260. Rivera MN, Kim WJ, Wells J, Stone A, Burger A, Coffman EJ, et al. The tumor suppressor WTX shuttles to the nucleus and modulates WT1 activity. Proc Natl Acad Sci U S A. 2009;106(20):8338-43.

261. Chen KS, Stroup EK, Budhipramono A, Rakheja D, Nichols-Vinueza D, Xu L, et al. Mutations in microRNA processing genes in Wilms tumors derepress the IGF2 regulator PLAG1. Genes Dev. 2018;32(15-16):996-1007.

262. Pode-Shakked N, Shukrun R, Mark-Danieli M, Tsvetkov P, Bahar S, Pri-Chen S, et al. The isolation and characterization of renal cancer initiating cells from human Wilms' tumour xenografts unveils new therapeutic targets. EMBO Mol Med. 2013;5(1):18-37.

263. Berry RL, Ozdemir DD, Aronow B, Lindstrom NO, Dudnakova T, Thornburn A, et al. Deducing the stage of origin of Wilms' tumours from a developmental series of Wt1-mutant mice. Dis Model Mech. 2015;8(8):903-17.

264. Hu Q, Gao F, Tian W, Ruteshouser EC, Wang Y, Lazar A, et al. Wt1 ablation and Igf2 upregulation in mice result in Wilms tumors with elevated ERK1/2 phosphorylation. J Clin Invest. 2011;121(1):174-83.

265. Huang L, Mokkapati S, Hu Q, Ruteshouser EC, Hicks MJ, Huff V. Nephron Progenitor But Not Stromal Progenitor Cells Give Rise to Wilms Tumors in Mouse Models with beta-Catenin Activation or Wt1 Ablation and Igf2 Upregulation. Neoplasia. 2016;18(2):71-81.

266. McDaniell R, Warthen DM, Sanchez-Lara PA, Pai A, Krantz ID, Piccoli DA, et al. NOTCH2 mutations cause Alagille syndrome, a heterogeneous disorder of the notch signaling pathway. Am J Hum Genet. 2006;79(1):169-73.

267. Kuure S, Sainio K, Vuolteenaho R, Ilves M, Wartiovaara K, Immonen T, et al. Crosstalk between Jagged1 and GDNF/Ret/GFRalpha1 signalling regulates ureteric budding and branching. Mech Dev. 2005;122(6):765-80.

268. Cheng HT, Kim M, Valerius MT, Surendran K, Schuster-Gossler K, Gossler A, et al. Notch2, but not Notch1, is required for proximal fate acquisition in the mammalian nephron. Development. 2007;134(4):801-11.

269. McCright B, Gao X, Shen L, Lozier J, Lan Y, Maguire M, et al. Defects in development of the kidney, heart and eye vasculature in mice homozygous for a hypomorphic Notch2 mutation. Development. 2001;128(4):491-502.

270. Takamiya K, Kostourou V, Adams S, Jadeja S, Chalepakis G, Scambler PJ, et al. A direct functional link between the multi-PDZ domain protein GRIP1 and the Fraser syndrome protein Fras1. Nat Genet. 2004;36(2):172-7.

271. Vogel MJ, van Zon P, Brueton L, Gijzen M, van Tuil MC, Cox P, et al. Mutations in GRIP1 cause Fraser syndrome. J Med Genet. 2012;49(5):303-6.

272. Bick D, Franco B, Sherins RJ, Heye B, Pike L, Crawford J, et al. Brief report: intragenic deletion of the KALIG-1 gene in Kallmann's syndrome. N Engl J Med. 1992;326(26):1752-5.

273. Pingault V, Bodereau V, Baral V, Marcos S, Watanabe Y, Chaoui A, et al. Loss-of-function mutations in SOX10 cause Kallmann syndrome with deafness. Am J Hum Genet. 2013;92(5):70724.

274. Young J, Metay C, Bouligand J, Tou B, Francou B, Maione L, et al. SEMA3A deletion in a family with Kallmann syndrome validates the role of semaphorin $3 \mathrm{~A}$ in human puberty and olfactory system development. Hum Reprod. 2012;27(5):1460-5.

275. Kyttala M, Tallila J, Salonen R, Kopra O, Kohlschmidt N, Paavola-Sakki P, et al. MKS1, encoding a component of the flagellar apparatus basal body proteome, is mutated in Meckel syndrome. Nat Genet. 2006;38(2):155-7.

276. Bergmann C, Frank V, Salonen R. Clinical utility gene card for: Meckel syndrome - update 2016. Eur J Hum Genet. 2016;24(8).

277. Kang S, Graham JM, Jr., Olney AH, Biesecker LG. GLI3 frameshift mutations cause autosomal dominant Pallister-Hall syndrome. Nat Genet. 1997;15(3):266-8. 
278. Cain JE, Islam E, Haxho F, Chen L, Bridgewater D, Nieuwenhuis E, et al. GLI3 repressor controls nephron number via regulation of Wnt11 and Ret in ureteric tip cells. PLoS One. 2009;4(10):e7313.

279. Sanyanusin P, Schimmenti LA, McNoe LA, Ward TA, Pierpont ME, Sullivan MJ, et al. Mutation of the PAX2 gene in a family with optic nerve colobomas, renal anomalies and vesicoureteral reflux. Nat Genet. 1995;9(4):358-64.

280. Bulum B, Ozcakar ZB, Ustuner E, Dusunceli E, Kavaz A, Duman D, et al. High frequency of kidney and urinary tract anomalies in asymptomatic first-degree relatives of patients with CAKUT. Pediatr Nephrol. 2013;28(11):2143-7.

281. Nicolaou N, Renkema KY, Bongers EM, Giles RH, Knoers NV. Genetic, environmental, and epigenetic factors involved in CAKUT. Nat Rev Nephrol. 2015;11(12):720-31.

282. van der Ven AT, Vivante A, Hildebrandt F. Novel Insights into the Pathogenesis of Monogenic Congenital Anomalies of the Kidney and Urinary Tract. J Am Soc Nephrol. 2018;29(1):36-50.

283. dos Santos Junior AC, de Miranda DM, Simoes e Silva AC. Congenital anomalies of the kidney and urinary tract: an embryogenetic review. Birth Defects Res C Embryo Today. 2014;102(4):374-81.

\section{Figure legends}

Figure 5.1. Illustration of the three developmental stages of kidney morphogenesis. A) Pronephros, the first kidney to form, is present in the fetus before the Wolffian duct (WD) makes the connection to cloaca (C), approximately at embryonic day 9.5 (E9.5). Nephrogenic cord (NC) is formed together with the WD and is depicted in light gray. B) Mesonephros development follows the pronephros and takes place concomitantly with WD fusion to cloaca (C). C) The last kidney to form is the metanephros or permanent kidney, which begins to develop when the NC has differentiated into metanephric mesenchyme (light green) and induces WD epithelium to bulge and form the ureteric bud (brown).

Figure 5.2. Schematic view of metanephros development A) Ureteric bud (UB) is divided into the trunk (dark brown) and tip (light brown) regions, which are already defined at the initial bud stage. The UB is surrounded by the metanephric mesenchyme (MM) while spindle cell stroma (S) encircles the MM. B) The UB branching begins by the formation of an ampulla at the tip of the UB. Simultaneously, the UB induces the MM to condense and form a pretubular aggregate (left of the UB tip, light green cells), which begins epithelialization into the nephron by forming the renal vesicle (right of the UB tip, green vesicle). C) The UB ampulla extends to develop two new tips while the renal vesicle further differentiates into comma-shaped body (right of the UB). D) UB tips continue to branch out with concurrent further connection of the comma-shaped body to the UB tips. Nephrogenesis continues by differentiation of the comma-shaped body into the S-shaped body (right of the UB). These events are reiterated until the end of branching morphogenesis when the final nephron differentiation burst uses up all remaining nephron progenitors in the metanephric mesenchyme, and in this way, each kidney attains its final nephron count.

Figure 5.3. Horseshoe kidney/renal fusion and multi-cystic dysplasia. A) A human horseshoe kidney at gestational week 13 (equal to 11 weeks of fetal development). The genetic cause for the horseshoe kidney in this fetus is trisomy 18. Fusion is always seen in the caudal part of the kidneys (arrow). B) Multicystic renal dysplasia is characterized by large cysts surrounded by 
clear cytoplasmic stromal cells. The cysts can be either in a segment of a kidney, in one whole kidney, or in both kidneys. Abbreviations; A, adrenal gland.

Figure 5.4. Nephroblastomatosis/Nephrogenic Rests. A) Normal human kidney at gestational week 12. Arrows point to differentiating nephron precursors. B) Nephrogenic rests are the dark blue, highly cellular islands in the subcortical or perilobar areas. They represent persistent foci of nephrogenic blastema in the postnatal kidney in a 1 year old child. Because he had multiple foci of nephrogenic rests (white asterisks), the condition is called nephroblastomatosis. Abbreviations; $\mathrm{G}$, glomerulus; $U$, ureteric bud; $\mathrm{S}$, stroma.

Figure 5.5. Wilms' tumor or nephroblastoma. A) Normal human kidney at gestational week 12. Arrow points to a ureteric bud, $B$ marks blastema (the metanephric mesenchyme), and $S$ is the stroma. B) The morphology of the classic Wilms' tumor (also called nephroblastoma) mimics that of embryonic kidneys showing blastemal (B), stromal (S), and epithelial cells (arrow) but in a disorganized manner. 